\title{
THE RELATIONSHIP BETWEEN INDULGENCE AND VANITY IN THE CONSUMPTION INTENTION
}

\author{
Juliane Ruffatto \\ Master \\ Universidade do Vale do Rio dos Sinos - UNISINOS. \\ Passo Fundo, RS - Brazil. \\ julianerufato@hotmail.com \\ Dandir Pauli \\ Post doctor \\ Faculdade Meridional - IMED. \\ Passo Fundo, RS - Brazil. \\ jandir.pauli@imed.edu.br

\section{Kenny Basso} \\ Doctor \\ Cooperando inteligência + interação. \\ Passo Fundo, RS - Brazil. \\ bassokenny@gmail.com
}

Purpose - Analyze the emergence of this market based on behavioral variables, with the objective of describing the relationship between indulgence, vanity, susceptibility to interpersonal influence and the need for social belongingness with the intent of consuming male aesthetic products.

Design/methodology/approach - A quantitative study was conducted, of the survey type, with male individuals. For the analysis of the data, the regression was used, based on moderation tests.

Findings - The results pointing to variables indulgence and vanity as important for the formation of the studied market. Furthermore, the susceptibility to interpersonal influence and the need to belong, tested as moderating variables between indulgence and consumption intention and between vanity and consumption intention, were significant, since both weaken the relationship between the main relationships, since they are variables that refer to the collective sense, and indulgence and vanity, to the more intrinsic, subjective sense of the individual.

Originality/value - This study debates the formation of intention consumption based on the Brazilian context, using a model that takes into consideration the integration between different variables established in the literature, showing how individual, cultural and symbolic factors interact in the formation of consumption intention. The data analysis reveals that the need to belong and interpersonal influence are moderating variables between indulgence and consumption intention and between vanity and consumption intention.

Theoretical / methodological contributions - Validation of a theoretical model, which has occurred, with statistical and theoretical support.

Keywords: Mercado da estética masculina. Indulgência. Vaidade. Intenção de consumo.

\section{How to cite the article}

American Psychological Association (APA)

Ruffatto, J., Pauli, J., \& Basso, K. (2021, July./Sept.). The relationship between indulgence and vanity in the consumption intention. Brazilian Journal of Marketing, 20(3), 415-436. https://doi.org/10.5585/remark.v20i3.17125. 


\section{Introduction}

Regarded as a growing market in Brazil, the male aesthetics market, also known as grooming market (Moungkhem; Surakiatpinyo, 2010), is an important issue that needs to be analyzed both in the academy and management communities. The Brazilian market for personal care products for men represents $13 \%$ of global sales. The forecast of the Euromonitor research institute is that, by 2021, Latin America will be the leader of world growth - with Brazil above the continent average (Euromonitor, 2020).

These changes in Brazil follow a worldwide trend as a growing market and the formation of markets requires a double movement: the refutation of the moral opposition that prevents the circulation of a certain good (Radin, 1996), and the moralization of market practice itself (Sen, 1985). In fact, the male aesthetic market implies a redefinition of the concept of masculinity (Connell, 2014), even if these consumers are permanently seeking their differentiation in relation to the feminine gender (Elliot; Elliot, 2005; Fontes; Borelli; Cassoti, 2012).

When analyzing the logic of a market formation solely through the lens of self- interest has proved to be quite limited (Bajde, 2006), since consumer behavior is embedded into the social relations typical of specific contexts (Frenzen; Davis, 1990; Dimaggio; Louch, 1998). Therefore, the present study intends to contribute to analyzing how the variables associated with self-interest are moderated by the logic of social interactions.

In order to understand the formation of consumer intention, the literature has emphasized the role of indulgence (Wiggin; Reimann; Jain, 2019) ), vanity (Abdala, 2008; Strehlau; Claro; Abraão Neto, 2015), individual susceptibility to interpersonal influence (Netemeyer; Bearden; Teel, 1992; Kropp; Lavack; Silvera, 2005) and the need to belong (Baumeister; Leary, 1995). This study suggests an analytical model that integrates these different aspects based on the assumption that individual variables are moderated by the social interactions of individuals in the formation of their consumption intention.

Recognizing that markets are social constructions and that they are also formed from interests, it is up to this study to investigate the relationship between the behavior of the interested party (microsocial) and the consumption intention to understand the formation of the male aesthetic market. Most classical studies and seminal studies on market formation emphasize the macro-social logic among economic actors manifested in the literature of economic sociology (Granovetter, 1973; Durkheim, 1975; Polanyi, 2000).

On the other hand, there are few empirical studies that discuss the formation of markets under the microsocial, individual logic, emphasizing the interested behavior. The study that 
comes closest to this logic and that considers the subjectivity of economic agents and their peculiarities is the research by Abramovay (2004). The available studies emphasize the issue from the perspective of female behavior, especially regarding the emotional content involved in consumer attitudes.

Considering the indulgence, vanity, susceptibility to interpersonal influence and the need to belong as influencers of behavior, as well as the global opening of markets and the emergence of new consumption patterns, it is important to analyze whether these variables have influence on the consumption intention of the consumer. interested individual. And, in the same way, they contribute to the formation of the male aesthetic market, bringing important theoretical contributions to marketing literature and market formation.

The Brazilian context is relevant to the analysis of the theme, since there is a phenomenon of growth in exclusive spaces to serve the male audience - customized beauty salons, in addition to the growth in the consumption of products by this specific audience.

\section{Theoretical background}

\section{Indulgence and vanity}

Indulgence means "pampering yourself", giving in to desire, allowing oneself gift, which often involves the act of spending on items perceived as luxury, such as alibis (excuses) which individuals rely in on to doing something that is not common practice, but, through selfperception of merit ("I deserve it!), becomes acceptable (Kivetz; Simonson, 2002).

In the context of consumer choice, indulgence is like allowing oneself to choose and enjoy the pleasure of an option that is regarded as a treat compared to alternative options (Berry, 1994; Prinsen; Evers; de Ridder, 2019), to comfort oneself when encountering some dissatisfaction or to reward oneself after achieving some goal (Xu, Schwarz, 2009). Therefore, people can make indulgent choices across a whole range of consumer domains (food, travel, clothing, personal care), which may include the best ingredients at a higher cost (Cavanaugh, 2014).

Consumers have found in indulgence a form therapy for routine issues, with the intent of improving mood or seeking pleasure (Clarke; Mortimer, 2013). Seeing indulgence as a trend is to understand that the consumer can and wants to develop new habits and tastes, because the power of indulgence overcomes health, financial and time constraints, everything is geared toward pleasure and self-perception of worthiness (Kivetz; Simonson, 2002). 
Hypothesis 1: Indulgence positively influences the intention to consume male aesthetic products.

On the other hand, vanity has proved to be an important predictor of consumer behavior, regarded as a psychological construct that indicates the concern of an individual with their own physical appearance, influenced by aesthetic standards that are culturally edified (Wang; Waller, 2006; Strehlau; Claro; Abrahão Neto, 2015).

Vanity is associated with caring oneself, often associated with beauty and health (Strehlau; Claro; Abrahão Neto, 2015). It can also be regarded as a healthy need to improve one's self -esteem and well-being, as a sort of passport towards happiness, success and all other positive things in life (Wang, Waller, 2006). Marketing images establish a connection with consumer vanity to different goods and services, such as perfumes, fashion items, luxury cars, diet products, surgeries, cosmetics, etc. (Wang, Waller, 2006).

Vanity has proved itself to be an important predictor of the consumer's self-awareness (Lee, Workman, 2014) and self-image (Sedikides et al., 2007; Ye; Robetson, 2012), with vain people being more susceptible to marketing efforts (Watson et al. al., 1999), willing to spend more on personal care (Wang, Waller, 2006). Therefore, the greater the physical vanity, the greater the consumption of aesthetic products and services (Abdala, 2008). Vanity may have an effect on the consumption of cosmetics and treatments, the frequency of cosmetic care and the individual's involvement with beauty (Strehlau; Claro; Abrahão Neto, 2015).

Thus, taking into account that the consumption of aesthetic products by the male audience may be regarded as a form of indulgence, seen as a self-fulfillment practice, and beauty products and services can be thought beyond their tangibility, but by the symbolism they represent, it is logical to assume that indulgence has a positive influence on the formation of male interest in the aesthetic market. Likewise, it is possible to consider that the need to feel attractive and the search for feeling good about oneself can positively influence the intention to consume aesthetic products which allow improving one's appearance, according to preestablished social and aesthetic standards.

Taking into account the existing literature on the influence of indulgence and vanity on the consumption of aesthetic products, the following hypotheses emerge in the attempt to understand the consumption intention in the specific market of masculine aesthetics: 
Hypothesis 2: Vanity positively influences the intention to consume male esthetic products.

Susceptibility to interpersonal influence and need to belong

Often, individuals change their consumption patterns motivated by social pressures (Netemeyer; Bearden; Teel, 1992; Kropp; Lavack; Silvera, 2005). These social pressures were named consumer susceptibility to interpersonal influence (Mcguire, 1968).

Netemeyer, Barden, and Tell (1992) point out that interpersonal influence is an important factor which determines consumer behavior, that considers the values and attitudes of other people or reference groups with whom one identifies, to define their consumption options. Therefore, the consumer susceptibility to interpersonal influence is regarded as a subjective characteristic of the individual, a personality trait, in other words, each subject has their own ability to respond to social influence (Netemeyer; Bearden; Teel, 1992).

Interpersonal influence is defined as the need to identify or improve one's own image based on the opinion of others, by purchasing and using products and brands, and is related to individual values, in other words, higher-order social cognitions that model attitudes and consumer behaviors, and self-esteem, a measure of social or collective identity (Kropp; Lavack; Silvera, 2005)

Subjects who are more susceptible to interpersonal influence have consumption choices and decisions that give more relevance to the opinions of other consumers than to their own traits or motivations, they value a need to belong, affectionate relationships with others, and they believe they will be more respected than those who are less susceptible to interpersonal influence (Kropp et al., 2000 ); therefore, they are more prone to purchase products that they deem more capable of improving their image in the eyes of the others (Netemeyer; Bearden, Teel, 1992).

Studies reveal that the choice for luxury brands is influenced by reference groups that are part of close relationships (Escalas; Bettman, 2005; Shukla, 2011) or external (Escalas; Bettman, 2005; Berger; Heath, 2007). They also indicate that the meanings associated with the consumption of reference groups help individuals to create their own identities (Mccracken, 1989), turning susceptibility to interpersonal influence a predictor of the need for exclusivity (Nabi; O'Cass; Siahtiri, 2019) or even as a strategy to avoid social rejection (Lee; Shrum, 2012).

Based on these forms of evidence, this study postulates whether or not the susceptibility to interpersonal influence can moderate the relationship hip between indulgence and vanity variables in the formation of the intention to consume male aesthetic products. This logic is expressed in the following hypothesis: 
Hypothesis 3a: The susceptibility to interpersonal influence moderates the relationship between indulgence and the intention to consume male aesthetic products, and the relationship between indulgence and consumption intention will be weaker depending on the increase of susceptibility to interpersonal influence.

Hypothesis 3b: The susceptibility to interpersonal influence moderates the relationship between vanity and the intention to consume male aesthetic products, and the relationship between vanity and consumption intention will be weaker depending on the increase of susceptibility to interpersonal influence.

Associated to the susceptibility to external influence, the need to belong (NTB) can also be understood based on a fundamental orientation of interpersonal relationships. Schutz (1966) indicates three basic needs underlying the collective behavior of people: inclusion, regarding the need to belong or include others in a circle of acquaintances; affection, or the need to love or be loved by others; and control, which includes the need to exercise power over others or to empower others (Schutz, 1966).

In order to establish and maintain social relationships, individuals must be sensitive to the thoughts and feelings of others. People need to be loved and socially accepted, this phenomenon is known as the need to belong (Baumeister; Leary, 1995; Leary et al., 2013; Leary; Baumeister, 2017). This need to belong of the human being is a crucial human motivation, something that all human beings have to establish and maintain at least a minimum amount of lasting, positive and meaningful interpersonal relationships (Baumeister \& Leary, 1995). The NTB forces the individual to make decisions based on the desire to form interpersonal connections, and not on intrinsic factors (Pickett; Gardner; Knowles, 2004). Individuals with greater need to belong fear being excluded and are more concerned with social connectivity than those with less need to belong (Baumeister; Leary, 1995).

Studies have revealed that consumers with a high NTB have a tendency to appropriate brand symbolism when the latter is endorsed by celebrities, influencing the search for parasocial relationships with celebrities and mediating the relationship between endorsement and brand, suggesting NTB as an indicator of concern regarding the consumer's social identity (Escalas; Bettman, 2017). Studies also indicate that NTB is associated with anthropomorphization (Epley et al., 2008) and the engagement with the team's positive behavior, showing itself as a moderator of the relationship between the brand and the positive word-to-mouth (Sicilia; Delgado-Ballester; Palazon, 2016). 
Before this theoretical framework, this study postulates whether or not the NTB has a moderating effect on the relationships between indulgence, vanity and the intention to consume male aesthetic products. Specifically, it is believed that higher levels of need to belong will lead the individual to relegate more selfish aspects (indulgence and vanity) to decision-making. Therefore, a greater need to belong will weaken the role of indulgence and vanity in the formation of the market of male aesthetic products. In contrast, the less need to belong the individuals have, the greater the relevance of indulgence and vanity for the establishment of this market. This logic is presented in the following hypotheses:

Hypothesis 4a: The need to belong moderates the relationship between indulgence and the intention to consume male aesthetic products, and the relationship between indulgence and consumption intention will be weaker depending on an increased need to belong.

Hypothesis 4b: The need to belong moderates the relationship between vanity and the intention to consume male aesthetic products, and the relationship between vanity and consumption intention will be weaker depending on an increased need to belong. Based on the research hypotheses, the theoretical model is shown in Figure 1.

Figure 1 - Theoretical model

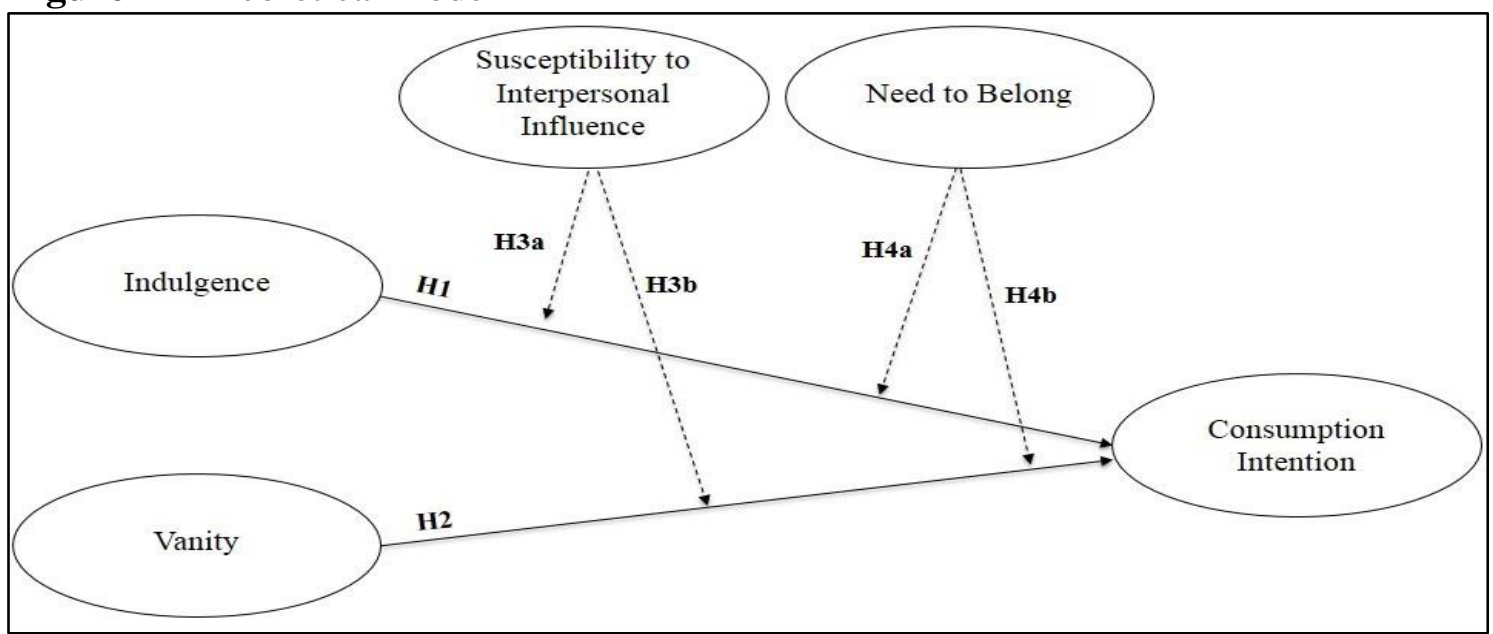

Source: Research data (2017).

\section{Methodology}

Taking into consideration the research question and the objectives outlined in this study, the most appropriate type of approach is the quantitative, descriptive, cross-sectional, with a Survey-based operationalization. 
The participants who took part in this study's sample, all males, over 18 years old, were recruited from a contact mailing list. The sample consisted of 377 cases, accessed by sampling for the sake of convenience. The research was operationalized by a questionnaire made available online on the Qualtrics platform.

To determine the minimum sample size, the rule of using at least 10 respondents for each observable variable was respected (Hair et al., 2005) or, at least, 200 respondents (Kline, 2005). Based on these parameters, the calculated sample is at least 290 cases (29 questions multiplied by 10 respondents). Thus, a sample of 377 valid cases was obtained, accessed in a non-probabilistic manner or for convenience, due to the technique used and the ease of access of the researcher.

The measures used in this research were adapted from other studies, particularly: i) scale of indulgence (Clarke; Mortimer, 2013); ii) vanity (Netemeyer; Burton; Lichtenstein, 1995); iii) scale of susceptibility to interpersonal influence (Consumer Susceptibility to Interpersonal Influence - SUSCEP) (Bearden; Netemeyer; Teel, 1989); iv) need to belong (Need to Belong Scale) by Leary et. al (2013) and v) consumption intention (Bruner; Hensel, 1998). In order to assess the respondent's intention to consume aesthetic products or services, an adapted Bruner and Hensel scale was used (1998). All measures used are included in the appendix, along with the reliability of each scale.

The end of the questionnaire presented some questions related to consumption, such as the type of consumption intention, past behavior, the frequency of consumption and, lastly, the sociodemographic characterization of respondents.

Before the data collection, a pre-test was conducted with 13 (thirteen) individuals belonging to the group of respondents from the research's scope. This procedure was carried out to verify the clarity of the form terms. Minor changes in the instrument flow were applied to simplify data collection.

After collected, the data were treated using the Statistical Package for Social Sciences ${ }^{\circledR}$ (SPSS) software. Before the data analysis, was verified that there is no multicollinearity between the constructs, since the highest bivariate correlation is between susceptibility to interpersonal influence and need to belong $(\mathrm{r}=0,59 ; \mathrm{p}<0,01)$. Additionally, there are homoscedasticity along the variances, verified through the Levene, Box'M and graphical analysis of the residues.

For data analysis, each construct comprised the average of the corresponding indicators (a comparative analysis comprising the constructs with the factorial score did not change the 
presented results). We use two procedures to test the theoretical model presented in the Figure 1. For the test of the $\mathrm{H} 1$ and $\mathrm{H} 2$ hypotheses, a multiple linear regression model (ordinary least squares) was used, whereas, for the test of the moderation hypotheses (H3 a, H3b, H4a, H4b) the MODPROBE script was used (Hayes; Matthes, 2009), using the Johnson-Neyman technique (Johnson; Fay, 1950) to identify the areas of significance of the relation, based on the levels of the moderator variable. The MODPROBE script used is based on ordinary least squares regression analysis. This script regressed the dependent variable by the independent variable, the moderator variable and the interaction term (independent variable $\mathrm{X}$ moderator variable).

\section{Results}

Sample profile

Regarding the age of the respondents, a predominance of the age 26-35 years old group $(50,7 \%)$ was detected, the mean age of the participants was 32,5 ( $\sigma=8,52$ years), most were single $(46 \%)$ and with postgraduate education level.

With the intent to measure the level at which the individuals involved intend or not to consume aesthetic products, in addition to the operationalization of the construct "consumption intention", whose base of scale was that of Bruner and Hensel (1998), a multiple-choice question was presented, focused on the type of consumption that would best shape this intention. The question divided the type of consumption into three groups: the first group gave a choice for those who want to consume a cosmetic item, a facial moisturizer, for instance; the second for those who want to consume something more invasive, such as plastic surgery for aesthetic purposes and, finally, an option for those who do not want to consume anything. Of the participants in this research, $47,7 \%$ have the intention to consume an aesthetic product such as a facial moisturizer, in turn, regarding a more invasive procedure like plastic surgery, only $13 \%$ showed interest and the percentage of those who do not intend to consume this type of product or service was $39,3 \%$.

Still focused on the consumption intention, the respondents were questioned about the use of services provided in beauty salons, barber shops and aesthetic clinics to undergo esthetic treatments besides hair cutting, 59\% said no, that they do not use other services in these spaces. 


\section{Test of $\mathrm{H1}$ and $\mathrm{H} 2$ hypotheses}

For the testing of $\mathrm{H} 1$ and $\mathrm{H} 2$ hypotheses, the multiple linear regression model took into consideration indulgence and vanity as independent variables and the consumption intention as the dependent variable. Specifically, the results of the model indicate that indulgence $(\beta=$ $0,454 ; \mathrm{t}=6,472 ; \mathrm{p}<0,001)$ and vanity $(\beta=0,414 ; \mathrm{t}=6,472 ; \mathrm{p}<0,001)$ have a positive effect on the consumption intention of male aesthetic products. These findings support the hypotheses $\mathrm{H} 1$ and $\mathrm{H} 2$, and uphold the premise that both indulgence and vanity are important factors for the establishment of this market.

Furthermore, based on these two antecedents (indulgence and vanity), the model explains $31 \%$ of the variations of the consumption intention $\left(\mathrm{R}^{2}=0,310\right)$. The equation $(1)$ presents the relationship between vanity and indulgence as predictors of the intention to consume aesthetic products.

$$
\gamma=0,684+0,454 * \text { Indulgence }+0,414 * \text { Vanity }+\varepsilon
$$

\section{Test of the H3a, H3b, H4a and H4b hypotheses}

Initially, in order to test the $\mathrm{H} 3$ and $\mathrm{H} 3 \mathrm{~b}$ hypotheses, susceptibility to interpersonal influence was regarded as the moderator variable, while indulgence $(\mathrm{H} 3 \mathrm{a})$ or vanity $(\mathrm{H} 3 \mathrm{~b})$ were seen as the focal predictors It must be emphasized that, when indulgence (vanity) was regarded as the focal predictor of consumption intention, vanity (indulgence) was also maintained as an additional predictor in the model, preserving the configurations of the model shown in equation 1 .

In the $\mathrm{H} 3 \mathrm{a}$ test, there was a positive effect of both indulgence $(\beta=0,852 ; \mathrm{t}=4,496 ; \mathrm{p}<$ $0,001)$ and vanity $(\beta=0,339 ; \mathrm{t}=5,452 ; \mathrm{p}<0,001)$ on consumption intention. The susceptibility to interpersonal influence also presented a positive effect on the consumption intention $(\beta=$ $0,780 ; \mathrm{t}=3,474 ; \mathrm{p}<0,001)$. More importantly, there is a significant effect of the interaction between indulgence and susceptibility to interpersonal influence on the intention to consume esthetic products $(\beta=-0,119 ; \mathrm{t}=-2,586 ; \mathrm{p}<0,05)$. The effect of this moderation is shown in figure 2, presenting as well the level of susceptibility in which the interpersonal influence of the relationship between indulgence and consumption intention is no longer significant. The results presented allow the acceptance of $\mathrm{H} 3 \mathrm{a}$. 
Figure 2 - Moderation of susceptibility to interpersonal influence in the relationship between indulgence and consumption intention

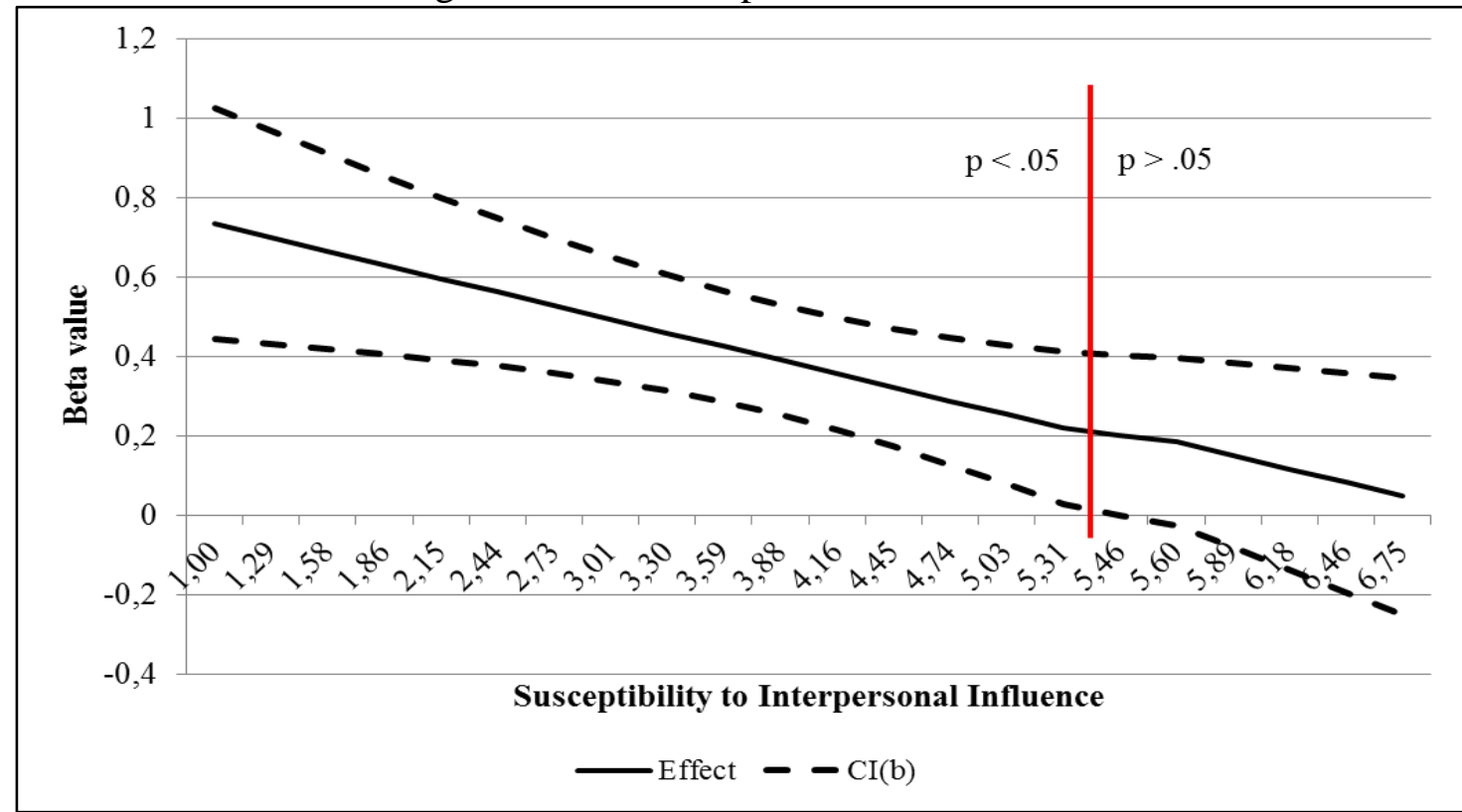

Source: Research data (2017).

As presented in Figure 2, the relationship between indulgence and consumption intention is significant for levels of susceptibility to interpersonal influence lower than 5.45. Therefore, when individuals have high levels of susceptibility to interpersonal influence (greater than 5,45 on a 7-point scale), indulgence is no longer an important predictor of consumption intention. It can also be inferred that, as levels of susceptibility to interpersonal influence increase, the effect of indulgence on the consumption intention is reduced.

Akin to what happened in the $\mathrm{H} 3 \mathrm{a}$ test, the $\mathrm{H} 3 \mathrm{~b}$ test presented a positive effect of both indulgence $(\beta=0,392 ; \mathrm{t}=5,659 ; \mathrm{p}<0,001)$ and vanity $(\beta=0,874 ; \mathrm{t}=5,801 ; \mathrm{p}<0,001)$ on the consumption intention. The susceptibility to interpersonal influence also had a positive effect on the consumption intention $(\beta=0,945 ; \mathrm{t}=4.730 ; \mathrm{p}<0,001)$. More importantly, there is a significant effect of the interaction between vanity and susceptibility to interpersonal influence on the intention to consume aesthetic products $(\beta=-0,142 ; \mathrm{t}=-3,788 ; \mathrm{p}<0,001)$. The effect of this moderation is presented in figure 3, which also indicates at what level of susceptibility to the interpersonal influence the relationship between vanity and the consumption intention is no longer significant. 
Figure 3 - Moderation of susceptibility to interpersonal influence in the relationship between vanity and consumption intention

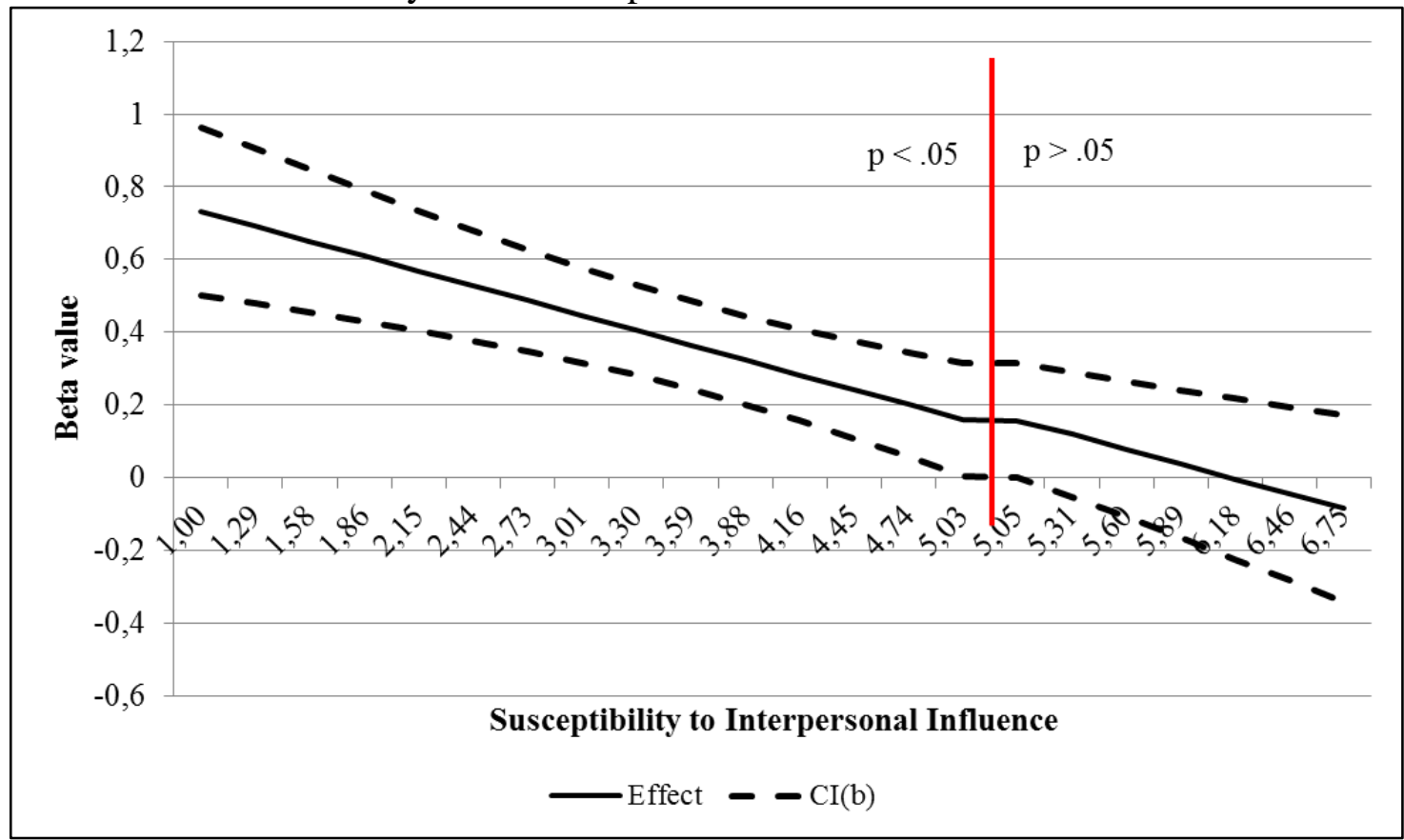

Source: Research data (2017).

As presented in Figure 3, the relationship between vanity and consumption intention is significant for levels of susceptibility to interpersonal influence lower than 5.05. Therefore, when individuals have high levels of susceptibility to interpersonal influence (greater than 5,05 on a 7-point scale), the effect of vanity on the consumption intention is no longer significant, and vanity is no longer an important predictor for the establishment of the market of male aesthetic products. These results uphold $\mathrm{H} 3 \mathrm{~b}$.

To test the hypotheses $\mathrm{H} 4 \mathrm{a}$ and $\mathrm{H} 4 \mathrm{~b}$, the need to belong was regarded as the moderator variable, whereas indulgence $(\mathrm{H} 4 \mathrm{a})$ or vanity $(\mathrm{H} 4 \mathrm{~b})$ were regarded as the focal predictors.

In the $\mathrm{H} 4 \mathrm{a}$ test, both indulgence $(\beta=0,885 ; \mathrm{t}=4,224 ; \mathrm{p}<0,001)$ and vanity $(\beta=0,344$; $t=5,478 ; p<0,001)$ had positive and significant effects on the consumption intention. The need to belong, as a moderator variable, also had a positive effect on the consumption intention $(\beta=$ $0,707 ; \mathrm{t}=3,072 ; \mathrm{p}<0,001)$. The effect of the interaction between indulgence and the need to belong on the intention to consume male aesthetic products was significant $(\beta=-0,113 ; \mathrm{t}=-$ 2,362; $\mathrm{p}<0.05)$. Figure 4 presents the results of this interaction that uphold the H4a hypothesis. 
Figure 4 - Moderation of the Need to Belong in the Relationship Between Indulgence and Consumption Intention

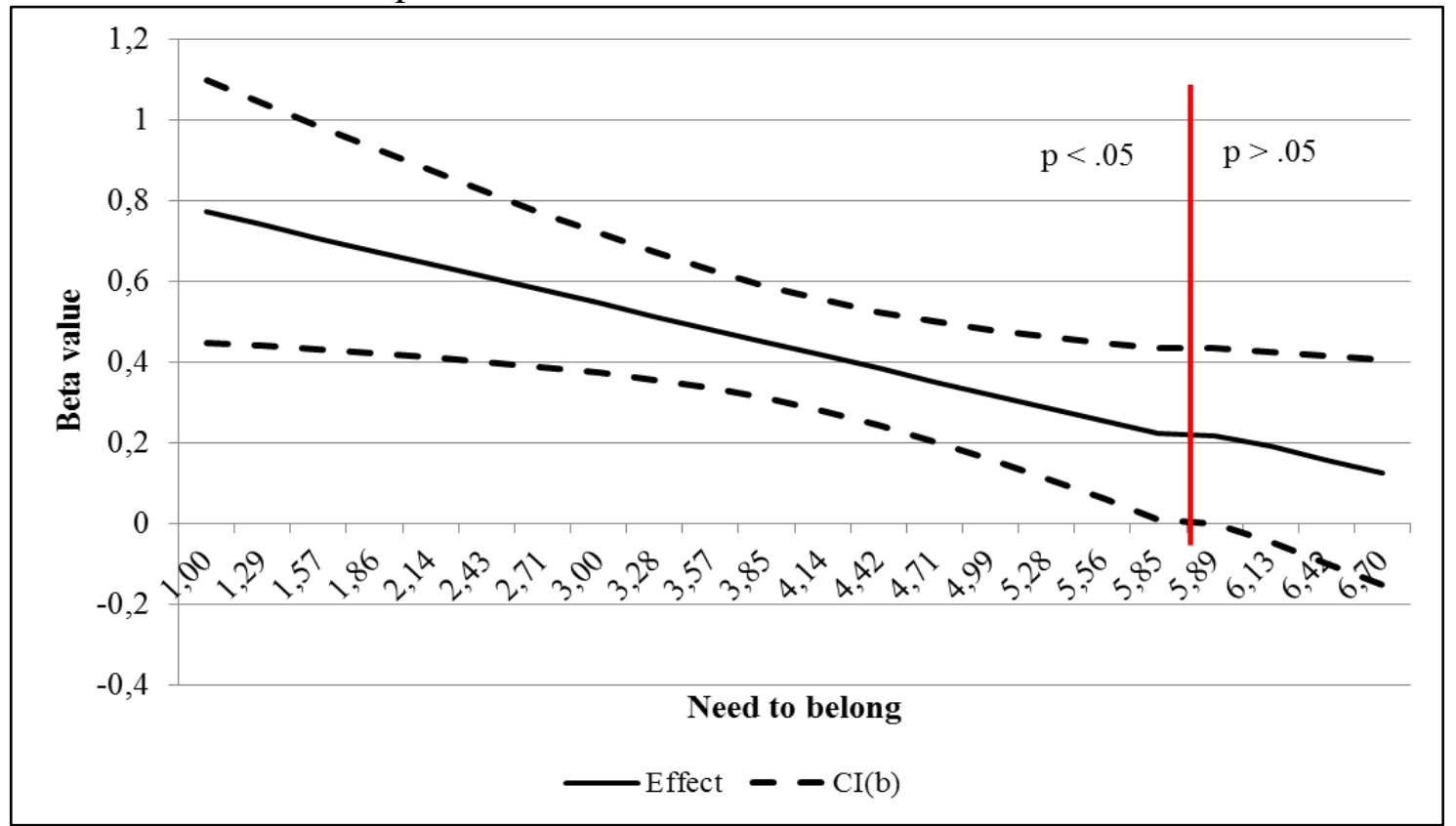

Source: Research data (2017).

The results obtained from the Johnson-Neyman test, presented in Figure 4, indicate that the relationship between indulgence and consumption intention is significant for levels of need to belong less than 5,89. Therefore, increasing the need to belong, as an individual trait, reduces the influence that indulgence has in the intention to consume masculine aesthetic products.

Finally, in the $\mathrm{H} 4 \mathrm{~b}$ test, both indulgence $(\beta=0,420 ; \mathrm{t}=6,149 ; \mathrm{p}<0,001)$ and vanity $(\beta$ $=1,026 ; \mathrm{t}=6,514 ; \mathrm{p}<0,001)$ had positive and significant effects on the consumption intention. The need to belong, as a moderator variable, also had a positive effect on the consumption intention $(\beta=1,084 ; t=5,294 ; p<0,001)$. The effect of the interaction between vanity and the need to belong on the intention to consume male aesthetic products was significant $(\beta=-0,177$; $\mathrm{t}=-4,579 ; \mathrm{p}<0,001)$. Figure 5 presents the results of this interaction. 
Figure 5 - Moderation of the Need to Belong in the Relationship Between Vanity and Consumption Intention

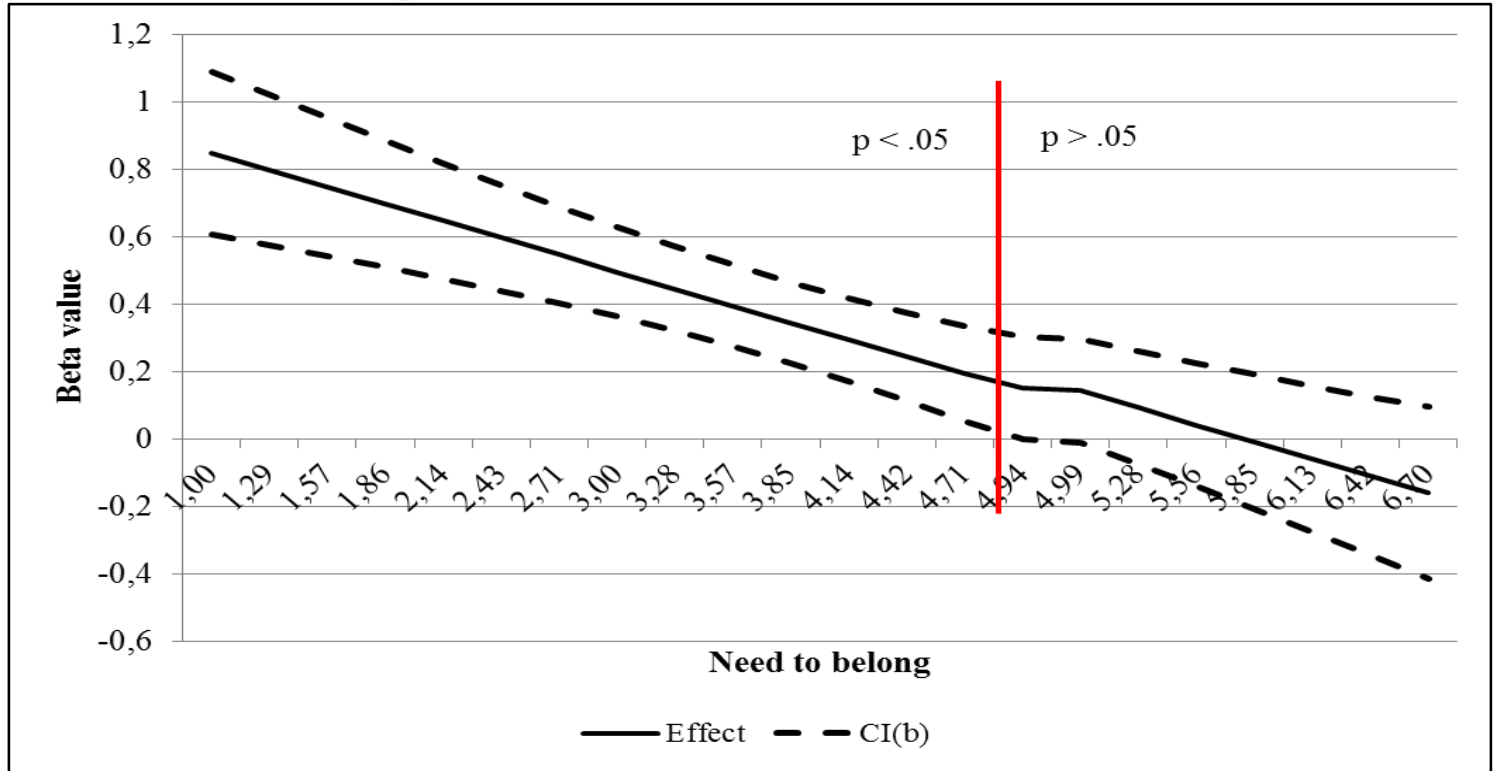

Source: Research data (2017).

According to Figure 5, the relationship between vanity and consumption intention is significant for levels of need to belong less than 4,94. Therefore, increasing the need to belong, as an individual trait, reduces the influence that vanity has in the intention to consume masculine aesthetic products. These findings uphold Hypothesis H4b.

Therefore, based on the study of the theoretical integrated model and on the adjustment indexes of the model to analyze the absolute adjustment measures suggested by Hair et al. (2009, the final result of the hypotheses raised was obtained (Table 1).

Table 1 - Synthesis of research results

\begin{tabular}{|c|c|}
\hline \multicolumn{2}{|l|}{ Research Hypotheses } \\
\hline $\begin{array}{l}\text { H1 - Indulgence positively influences the intention to consume male aesthetic products } \\
(\beta=0,454 ; \mathrm{t}=6,472 ; p<0,001) \text {. }\end{array}$ & Not rejeited \\
\hline $\begin{array}{l}\text { H2 - Vanity positively influences the intention to consume male esthetic products }(\beta= \\
0,414 ; \mathrm{t}=6,472 ; \mathrm{p}<0,001) .\end{array}$ & Not rejeited \\
\hline $\begin{array}{l}\text { H3a - The susceptibility to interpersonal influence moderates the relationship between } \\
\text { indulgence and the intention to consume male aesthetic products, and the relationship } \\
\text { between indulgence and consumption intention will be weaker depending on the increase } \\
\text { of susceptibility to interpersonal influence }(\beta=-0,119 ; \mathrm{t}=-2,586 ; \mathrm{p}<0,05) \text {. }\end{array}$ & Not rejeited \\
\hline $\begin{array}{l}\text { H3b - The susceptibility to interpersonal influence moderates the relationship between } \\
\text { vanity and the intention to consume male aesthetic products, and the relationship } \\
\text { between vanity and consumption intention will be weaker depending on the increase of } \\
\text { susceptibility to interpersonal influence }(\beta=-0,142 ; t=-3,788 ; p<0,001) \text {. }\end{array}$ & Not rejeited \\
\hline $\begin{array}{l}\text { H4a - The need to belong moderates the relationship between indulgence and the } \\
\text { intention to consume male aesthetic products, and the relationship between indulgence } \\
\text { and consumption intention will be weaker depending on an increased need to belong ( } \beta \\
=-0,113 ; \mathrm{t}=-2,362 ; \mathrm{p}<0.05) \text {. }\end{array}$ & Not rejeited \\
\hline $\begin{array}{l}\text { H4b - The need to belong moderates the relationship between indulgence and the } \\
\text { intention to consume male aesthetic products, and the relationship between indulgence }\end{array}$ & Not rejeited \\
\hline
\end{tabular}


and consumption intention will be weaker depending on an increased need to belong ( $\beta$ $=-0,177 ; \mathrm{t}=-4,579 ; \mathrm{p}<0,001)$.

Source: Elaborated by the authors (2017).

\section{Discussion}

The study has tested the model with the indulgence and vanity variables as a precedent for the establishment of a market of male aesthetic products $(\mathrm{H} 1$ and $\mathrm{H} 2)$. The results show that both indulgence and vanity are important factors for the formation of this market.

In the academic context, this confirmation is in line with theoretical propositions which indicate that indulgence influences the consumption (XU; SCHWARZ, 2009; PETERSEN, 2012; CAVANAUGH; 2014), in the sense that comfort and reward are the major motivators of indulgent consumption. Likewise, as a psychological construction, vanity is a factor that influences the consumption intention (BLOCH; RICHINS, 1992).

Hypotheses $3 \mathrm{a}$ and $3 \mathrm{~b}$ predicted the moderating effect of susceptibility to the interpersonal influence, between indulgence and consumption intention, and between vanity and consumption intention. The literature review indicated that people are susceptible to interpersonal influence on consumer issues (NETEMEYER; BEARDEN; TEEL, 1992).

The results of this study uphold the $\mathrm{H} 3 \mathrm{a}$ and $\mathrm{H} 3 \mathrm{~b}$ hypotheses, indicating that the relationship between indulgence for the establishment of the market of male esthetic products is conditioned by the profile of this market's actors. Therefore, the significance of indulgence is greater when the subjects do not have as much susceptibility to interpersonal influence, since the increase of this susceptibility decreases the significance of indulgence for the establishment of the market for these products. Likewise, when subjects have high levels of susceptibility to interpersonal influence, the importance of vanity for the establishment of the market of male aesthetic products is no longer significant, and vanity is no longer an important predictor.

Hypotheses $4 \mathrm{a}$ and $4 \mathrm{~b}$ predicted the moderating effect of the need to belong between indulgence and consumption intention and between vanity and the consumer's consumption intention, and these relationships become weaker with an increased need to belong. The relationship between indulgence and consumption intention is significant for lower levels of need to belong, as well as for the relation between vanity and consumption intention.

Therefore, the increase in the need to belong decreases the influence that indulgence and vanity have in the intention to consume male aesthetic products, in other words, indulgence and vanity are more intrinsic characteristics, and the need to belong refers to the collective aspect of things, to social connectivity (PICKETT; GARDNER; KNOWLES, 2004). The vainest 
individual does not depend on the need to belong to consume, since vanity is a more individualistic trait.

Featherstone (1991) already pointed to the importance of understanding the connection variants between the consumer and the product, as well as how these connections are established and kept. Following this reasoning, we brought up the question of this research, involving subjective and behavioral issues in consumption, understanding these issues as determinants for market formation.

\section{Conclusion}

This work is expected to contribute to a better understanding of the influences exerted by the consumer's indulgence and vanity in the consumption intention and subsequent establishment of a market, unfurling new theoretical discussions on the subject. Likewise, it is also expected to contribute to business managers for better planning of marketing strategies, and in the difficult task of understanding the characteristics of the consumers that influence attitudes and behavior of purchase.

One of the contributions of this study to academic research is in the validation of a theoretical model, which has occurred, with statistical and theoretical support. In the empirical study, it was observed that the main relationships involving indulgence and vanity in the intention of consumption are strongly related and that indulgence and vanity are consumer behaviors that contribute to the intention to consume male aesthetic products.

As for managerial contributions, this study brought important information to be able to direct companies to new job opportunities and the definition of strategies. A new consumer profile is being developed, diversified and demanding customers require specialized professionals and reliable establishments. The entrepreneur needs to be up-to-date and speak the same language as the audience he intends to reach. The connection with the consumer in niche markets needs to be much more intense and direct.

Administrators who work with aesthetic products or services aimed at the male audience must consider indulgence and all the emotional factors attached to it to organize their environments and design an advertising campaign. For entrepreneurs who intend to enter this booming market, they must consider indulgence as an essential component of consumer behavior and think of their business as an environment or a product to satisfy a desire, which consumers, in addition to physical consumption, intend to satisfy their pleasure. 
Global movements point to macro and megatrends in which calls for faster, very concrete, are everywhere and, at the other end, there is a strong sensitivity for slowing down and relaxing, which seems to announce new behaviors. Consumers increasingly seek sensory experiences. Inspiring new brands, new concepts and ventures, as well as creating new products and services will help to offer these experiences to consumers. And successful experiences indicate guidelines for conscious consumption. Wellness trends with a look at fashion marks a new, more integral vision of how the beauty sector can provide satisfaction, well-being and health, as, according to recent studies, it is known that choices and behaviors have the most impact on happiness, longevity and health than genetic inheritance.

\section{References}

ABDALA, P. R. Z. Vaidade e Consumo: Como a vaidade física influencia o comportamento do consumidor. Porto Alegre: UFRGS, 2008. Dissertação (Mestrado em Administração) Programa de Pós-Graduação em Administração da Universidade Federal do Rio Grande do Sul, Porto Alegre, RS, 2008.

BAJDE, D. Other-centered behavior and the dialectics of self and other. Consumption, Markets and Culture, v. 9, n. 4, p. 301-316, 2006.

BAUMEISTER, R. F.; LEARY, M. R. The need to belong: desire for interpersonal attachments as a fundamental human motivation. Psychological bulletin, v. 117, n. 3, p. 497, 1995.

BEARDEN, W. O.; NETEMEYER, R. G.; TEEL, J. E. Measurement of consumer susceptibility to interpersonal influence. Journal of consumer research, p. 473-481, 1989.

BERGER, Jonah; HEATH, Chip. Where consumers diverge from others: Identity signaling and product domains. Journal of Consumer Research, v. 34, n. 2, p. 121-134, 2007.

BERRY, C. J. The Idea of Luxury. Cambridge, UK: Cambridge University Press, 1994.

BLOCH, P.; RICHINS, M. You look "mahvelous": the pursuit of beauty and the marketing concept. Journal of Psychology \& Marketing, v. 9, n. 1, p. 3-15, 1992.

BRUNER, G.C. II; HENSEL, P.J. Marketing Scales Handbook: a Compilation of Multiitems Measures. Chicago: American Marketing Association, v. 2, 1998.

CAVANAUGH, L. A. Because I (don't) deserve it: How relationship reminders and deservingness influence consumer indulgence. Journal of Marketing Research, v. 51, n. 2, p. 218-232, 2014.

CLARKE, P. D.; MORTIMER, G. Self-gifting guilt: an examination of self-gifting motivations and post purchase regret. Journal of Consumer Marketing, v. 30, n. 6, p. $472-$ 483, 2013. 
CONNELL, R. The study of masculinities. Qualitative Research Journal, v. 14, n. 1, p. 5-15, 2014.

DE MOOIJ, M.; HOFSTEDE, G. Convergence and divergence in consumer behavior: implications for international retailing. Journal of retailing, v. 78, n. 1, p. 61-69, 2002.

DIMAGGIO, P.; LOUCH, H. Socially embedded consumer transactions: For what kinds of purchases do people most often use networks?. American sociological review, p. 619-637, 1998.

DURVASULA, S.; LYSONSKI, S. A double-edged sword: understanding vanity across cultures. Journal of Consumer Marketing, v. 25, n. 4, p. 230-244, 2008.

ELLIOTT, C.; ELLIOTT, R. Idealized Images of the Male Body in Advertising: A Reader Response Exploration. Journal of Marketing Communications, v. 11, n. 1, p. 3-19, 2005.

EPLEY, N.; WAYTZ, A.; AKALIS, S.; CACIOPPO, J. T. When we need a human: Motivational determinants of anthropomorphism. Social cognition, v. 26, n. 2, p. 143-155, 2008 .

ESCALAS, J. E.; BETTMAN, J. R. Self-construal, reference groups, and brand meaning. Journal of consumer research, v. 32, n. 3, p. 378-389, 2005.

ESCALAS, J. E.; BETTMAN, J. R. Connecting with celebrities: how consumers appropriate celebrity meanings for a sense of belonging. Journal of Advertising, v. 46, n. 2, p. 297-308, 2017.

EUROMONITOR INTERNATIONAL, 2020. Disponível em: https://go.euromonitor.com/white-paper-beauty--personal-care-20-11-03-survey-keyfindings.html. Acesso em: 22 fev. 2021.

FEATHERSTONE, M. The body in consumer culture. In: FEATHERSTONE, M.; HEPWORTH, M.; TURNER, B. (Ed.). The Body - Social Process and Cultural Theory. London, pp.170-96, 1991.

FONTES, O. A.; BORELLI, F. C.; CASOTTI, L. M. Como ser homem e ser belo? Um estudo exploratório sobre a relação entre masculinidade e o consumo de beleza. REAd-Revista Eletrônica de Administração, v. 18, n. 2, 2012.

FRENZEN, J. K.; DAVIS, H. L. Purchasing behavior in embedded markets. Journal of Consumer Research, v. 17, n. 1, p. 1-12, 1990.

GARCIA, W. O Corpo contemporâneo: A Imagem do metrossexual no Brasil. Revista de Humanidades, v. 5, n. 11, 2004.

GARCIA, W. O metrossexual no Brasil: estudos contemporâneos. São Paulo: Factash Editora, 2011. 
HAIR, J. F., BLACK, W. C., BABIN, B. J., ANDERSON, R. E., TATHAM, R. L. Análise multivariada de dados. Porto Alegre: Bookman, 6. ed, 2009.

HAYES, A. F.; MATTHES, J. Computational procedures for probing interactions in OLS and logistic regression: SPSS and SAS implementations. Behavior Research Methods, 41, 924936, 2009.

JOHNSON, P. O.; FAY, L. C. The Johnson-Neyman technique, its theory and application. Psychometrika, 15(4), 349-367, 1950.

KIVETZ, R.; SIMONSON, I. Earning the right to indulge: Effort as a determinant of customer preferences toward frequency program rewards. Journal of Marketing Research, v. 39, n. 2, p. 155-170, 2002.

KROPP, F.; JONES, M.; ROSE, G.; SHOHAM, A.; FLORENTHAL, B.; CHO, B. Group identities: A cross-cultural comparison of values and group influences. Journal of Euromarketing, v. 8, n. 1-2, p. 117-131, 2000.

KROPP, F.; LAVACK, A. M.; SILVERA, D. H. Values and collective self-esteem as predictors of consumer susceptibility to interpersonal influence among university students. International Marketing Review, v. 22, n. 1, p. 7-33, 2005.

LEARY, M. R.; BAUMEISTER, R. F. The need to belong: Desire for interpersonal attachments as a fundamental human motivation. In: Interpersonal development. Routledge, 2017. p. 57-89.

LEARY, M. R.; KELLY, K. M.; COTTRELL, C. A.; SCHREINDORFER, L. S. Construct validity of the need to belong scale: Mapping the nomological network. Journal of personality assessment, v. 95, n. 6, p. 610-624, 2013.

LEE, J.; SHRUM, L. J. Conspicuous consumption versus charitable behavior in response to social exclusion: A differential needs explanation. Journal of Consumer Research, v. 39, n. 3, p. 530-544, 2012.

LEE, S.; WORKMAN, J. Vanity, fashion leadership, and self-consciousness among South Korean male and female college students. International Journal of Fashion Design, Technology and Education, v. 7, n. 2, p. 115-124, 2014.

McGUIRE, W. J. Personality and susceptibility to social influence. Handbook of personality theory and research, v. 2, p. 1130-1187, 1968.

MILLAN, E.; WRIGHT, L. T. Gender effects on consumers' symbolic and hedonic preferences and actual clothing consumption in the Czech Republic. International Journal of Consumer Studies, v. 42, n. 5, p. 478-488, 2018.

MOUNGKHEM, C.; SURAKIATPINYO, J. A study of factors affecting on men's skin care products purchasing, particularly in Karlstad, Sweden. Karlstad, Sweden: Karlstad University, 2010. 
NABI, N.; O'CASS, A.; SIAHTIRI, V. Status consumption in newly emerging countries: The influence of personality traits and the mediating role of motivation to consume conspicuously. Journal of Retailing and Consumer Services, v. 46, p. 173-178, 2019.

NETEMEYER, R. G.; BEARDEN, W. O., TEEL, J. E. Consumer susceptibility to interpersonal influence and atributional sensitivity. Psychology \& Marketing, Vol. 9, N.5, p. 379-394, 1992.

NETEMEYER, R. G.; BURTON, S.; LICHTENSTEIN, D. R. Trait aspects of vanity: Measurement and relevance to consumer behavior. Journal of consumer research, p. 612-626, 1995.

PETERSEN, F. E. When do consumers indulge in luxury? Emotional certainty signals when to indulge to regulate affect. ESMT Working Paper, No. 12-06, 2012.

PICKETT, C. L.; GARDNER, W. L.; KNOWLES, M. Getting a cue: The need to belong and enhanced sensitivity to social cues. Personality and Social Psychology Bulletin, v. 30, n. 9, p. 1095-1107, 2004.

PRINSEN, S.; EVERS, C.; DE RIDDER, D. TD. Justified indulgence: self-licensing effects on caloric consumption. Psychology \& health, v. 34, n. 1, p. 24-43, 2019.

RADIN, M. J. Contested commodities. Harvard University Press, 1996.

SANDHYA, A. S.; MOHAMED, H. P. Understanding the attitude of men towards fairness cream in India. Asia Pacific Business Review, v. 5, n. 2, p. 126-133, 2009.

SCHUTZ, W. C. The Interpersonal Underworld: By William C. Schutz. Palo Alto: Science and Behavior Books, 1966.

SEDIKIDES, C.; GREGG, A. P.; CISEK, S.; HART, C. M. The I that buys: Narcissists as consumers. Journal of Consumer Psychology, v. 17, n. 4, p. 254-257, 2007.

SEN, A. The moral standing of the market. Social philosophy and policy, v. 2, n. 2, p. 1-19, 1985.

SHUKLA, P. Impact of interpersonal influences, brand origin and brand image on luxury purchase intentions: Measuring interfunctional interactions and a cross-national comparison. Journal of world business, v. 46, n. 2, p. 242-252, 2011.

SICILIA, M.; DELGADO-BALLESTER, E.; PALAZON, M. The need to belong and selfdisclosure in positive word-of-mouth behaviours: The moderating effect of self-brand connection. Journal of Consumer Behaviour, v. 15, n. 1, p. 60-71, 2016.

SOUIDEN, N.; DIAGNE, M. Canadian and French men's consumption of cosmetics: a comparison of their attitudes and motivations. Journal of Consumer Marketing, v. 26, n. 2, p. 97-109, 2009. 
STEINER, P; TRESPEUCH M. Maîtriser les passions, construire l'intérêt. Les jeux d'argent en ligne et les organes humains à l'épreuve du marché, Revue française de sociologie, v. 54, p. 155-180, 2013.

STREHLAU, V. I.; CLARO, D. P; ABRAÃO NETO, S. L. A vaidade impulsiona o consumo de cosméticos e de procedimentos estéticos cirúrgicos nas mulheres? Uma investigação exploratória. Revista de Administração, v. 50, n. 1, p. 73, 2015.

TROISI, J. D.; GABRIEL, S. Chicken Soup Really Is Good for the Soul "Comfort Food" Fulfills the Need to Belong. Psychological Science, 2011.

WANG, P. Z.; WALLER, D. S. Measuring consumer vanity: A cross-cultural validation. Psychology \& Marketing, v. 23, n. 8, p. 665-687, 2006.

WATSON, J. J.; RAYNER, R. S.; LYSONSKI, S.; DURVASULA, S. Vanity and advertising: A study of the impact of appearance-related, sex, and achievement appeals. ACR North American Advances, 1999.

WEBER, J. M.; CAPITANT DE VILLEBONNE, J. Differences in purchase behavior between France and the USA: the cosmetic industry. Journal of Fashion Marketing and Management: An International Journal, v. 6, n. 4, p. 396-407, 2002.

WIGGIN, Kyra L.; REIMANN, Martin; JAIN, Shailendra P. Curiosity tempts indulgence. Journal of Consumer Research, v. 45, n. 6, p. 1194-1212, 2019

XU, J.; SCHWARZ, N. Do we really need a reason to indulge? Journal of Marketing Research, v. 46, n. 1, 2009.

YE, L.; ROBERTSON, T. M. Gender Identity: Does It Matter for Consumers' Perceptions? Journal of business diversity, v. 12, n. 3, p. 81-92, 2012.

\section{Appendix A}

\begin{tabular}{|c|c|c|c|c|}
\hline Construct & Items of Scale & Average & $\begin{array}{r}\text { Standard } \\
\text { deviation }\end{array}$ & Reliability \\
\hline \multirow{5}{*}{ Indulgence } & IND1 I like to please myself. & 5,62 & 1,398 & \multirow{5}{*}{0,734} \\
\hline & IND2 I buy things for my pleasure. & 5,14 & 1,558 & \\
\hline & IND3 I like to spend money. & 3,68 & 1,788 & \\
\hline & IND4 I buy things without thinking. & 2,68 & 1,611 & \\
\hline & IND5 I like the good things in life. & 6,05 & 1,271 & \\
\hline \multirow{5}{*}{ Vanity } & $\begin{array}{l}\text { VAN1 The way I introduce myself is } \\
\text { quite important to me. }\end{array}$ & 5,44 & 1,262 & \multirow{5}{*}{0,893} \\
\hline & $\begin{array}{l}\text { VAN2 I'm quite worried about my } \\
\text { appearance. }\end{array}$ & 5,07 & 1,372 & \\
\hline & $\begin{array}{l}\text { VAN3 I feel embarrassed if I don't look } \\
\text { my best in public. }\end{array}$ & 4,62 & 1,666 & \\
\hline & $\begin{array}{l}\text { VAN4 Looking better is worth the } \\
\text { effort. }\end{array}$ & 5,14 & 1,506 & \\
\hline & $\begin{array}{l}\text { VAN5 Looking good at all times is } \\
\text { important. }\end{array}$ & 5,24 & 1,449 & \\
\hline $\begin{array}{l}\text { Susceptibility to } \\
\text { Interpersonal Influence }\end{array}$ & $\begin{array}{l}\text { INF1 I often check with other people to } \\
\text { choose the best alternative. }\end{array}$ & 4,14 & 1,648 & 0,885 \\
\hline
\end{tabular}




\begin{tabular}{|c|c|c|c|c|}
\hline Construct & Items of Scale & Average & $\begin{array}{l}\text { Standard } \\
\text { deviation }\end{array}$ & Reliability \\
\hline & $\begin{array}{l}\text { INF } 2 \text { To be sure of a product, I often } \\
\text { look at what others do. }\end{array}$ & 4,09 & 1,567 & \\
\hline & $\begin{array}{l}\text { INF } 3 \text { If I have little experience, I ask } \\
\text { my friends. }\end{array}$ & 4,77 & 1,720 & \\
\hline & $\begin{array}{l}\text { INF } 4 \text { I look for information with my } \\
\text { friends about products before buying } \\
\text { them. }\end{array}$ & 4,46 & 1,718 & \\
\hline & $\begin{array}{l}\text { INF } 5 \text { I often identify myself with other } \\
\text { people by buying the same products. }\end{array}$ & 3,89 & 1,699 & \\
\hline & $\begin{array}{l}\text { INF6 I try to buy products that others } \\
\text { approve. }\end{array}$ & 3,89 & 1,768 & \\
\hline & $\begin{array}{l}\text { INF } 7 \text { I would like to know which } \\
\text { products are positively accepted by other } \\
\text { people. }\end{array}$ & 3,91 & 1,799 & \\
\hline & $\begin{array}{l}\text { INF } 8 \text { I always wait for people to buy } \\
\text { things so that I can purchase similar } \\
\text { items }\end{array}$ & 2,96 & 1,674 & \\
\hline \multirow{10}{*}{ Need to Belong } & $\begin{array}{l}\text { BEL1 I'm affected if other people don't } \\
\text { seem to accept me. }\end{array}$ & 3,87 & 1,771 & \multirow{10}{*}{0,902} \\
\hline & $\begin{array}{l}\text { BEL2 I try hard not to do things that will } \\
\text { make other people avoid me or reject } \\
\text { me. }\end{array}$ & 3,83 & 1,837 & \\
\hline & $\begin{array}{l}\text { BEL3 I consider important that other } \\
\text { people care about me. }\end{array}$ & 4,33 & 1,687 & \\
\hline & $\begin{array}{l}\text { BEL4 I need to feel that there are people } \\
\text { I can rely on in case of need. }\end{array}$ & 4,61 & 1,680 & \\
\hline & BEL5 I want other people to accept me. & 4,16 & 1,776 & \\
\hline & BEL6 I don't like being alone. & 4,19 & 1,893 & \\
\hline & $\begin{array}{l}\text { BEL7 I'm affected if I stay away from } \\
\text { my friends for long periods of time. }\end{array}$ & 4,43 & 1,790 & \\
\hline & $\begin{array}{l}\text { BEL8 I have a strong "need to belong" } \\
\text { (friends, co-workers, society). }\end{array}$ & 4,20 & 1,666 & \\
\hline & $\begin{array}{l}\text { BEL9 It bothers quite a lot when I'm not } \\
\text { included in other people's plans. }\end{array}$ & 3,95 & 1,674 & \\
\hline & $\begin{array}{l}\text { BEL10 My feelings are easily hurt when } \\
\text { I feel that others don't accept me. }\end{array}$ & 3,60 & 1,835 & \\
\hline \multirow{5}{*}{ Consumer Intention } & INT1 Unlikely - Probable & 4,82 & 1,696 & \multirow{5}{*}{0,960} \\
\hline & INT2 Inexistent - Existent & 4,83 & 1,730 & \\
\hline & INT3 Not Plausible - Plausible & 4,83 & 1,602 & \\
\hline & INT4 Impossible - Possible & 5,19 & 1,548 & \\
\hline & INT5 Uncertain - Certain & 4,84 & 1,663 & \\
\hline
\end{tabular}




\section{A RELAÇÃO ENTRE INDULGÊNCIA E VAIDADE NA INTENÇÃO DE CONSUMO}

Juliane Ruffatto

Mestra

Universidade do Vale do Rio dos Sinos - UNISINOS

Passo Fundo, RS - Brasil

julianerufato@ hotmail.com

Jandir Pauli

Pós-doutor

Faculdade Meridional - IMED

Passo Fundo, RS - Brasil

jandir.pauli@imed.edu.br

Kenny Basso

Doutor

Cooperando inteligência + interação

Passo Fundo, RS - Brasil

bassokenny@gmail.com

Objetivo: Analisar a emergência do mercado da estética masculina com base em variáveis comportamentais, com o objetivo de descrever a relação entre indulgência, vaidade, suscetibilidade à influência interpessoal e a necessidade de pertencimento social com a intenção de consumir produtos estéticos masculinos.

Método: Foi realizado um estudo quantitativo, do tipo survey, com indivíduos do sexo masculino. Para a análise dos dados, foi utilizada a regressão, com base em testes de moderação.

Resultados: Os resultados apontam para as variáveis indulgência e vaidade como importantes para a formação do mercado da estética masculina. Além disso, a suscetibilidade à influência interpessoal e a necessidade de pertencer, testadas como variáveis moderadoras entre indulgência e intenção de consumo e entre vaidade e intenção de consumo, foram significativas, uma vez que ambas enfraquecem a relação entre os principais relacionamentos, pois são variáveis que se referem ao senso coletivo, enquanto que indulgência e vaidade, ao sentido mais intrínseco e subjetivo do indivíduo.

Originalidade/valor: Este estudo discute a formação do consumo intencional com base no contexto brasileiro, utilizando um modelo que leva em consideração a integração entre diferentes variáveis estabelecidas na literatura, mostrando como os fatores individuais, culturais e simbólicos interagem na formação da intenção de consumo. A análise dos dados revela que a necessidade de pertencer e a influência interpessoal são variáveis moderadoras entre indulgência e intenção de consumo e entre vaidade e intenção de consumo.

Contribuições teóricas/metodológicas: Validação de um modelo teórico, o que ocorreu com suporte estatístico e teórico.

Palavras-chave: mercado da estética masculina; indulgência; vaidade; intenção de consumo.

\section{Como citar}

American Psychological Association (APA)

Ruffatto, J., Pauli, J., \& Basso, K. (2021, jul./set.). A relação entre indulgência e vaidade na intenção de consumo. Revista Brasileira de Marketing - ReMarK, 20(3), 395-418. https://doi.org/10.5585/remark.v20i3.17125. 


\section{Introdução}

Considerado um mercado em crescimento no Brasil, o mercado de estética masculina, também conhecido como mercado de grooming (Moungkhem; Surakiatpinyo, 2010), é uma questão importante que precisa ser analisada tanto na comunidade acadêmica quanto na de gestão. O mercado brasileiro de produtos de higiene pessoal para homens representa 13\% das vendas globais. A previsão do instituto de pesquisas Euromonitor é que, até 2021, a América Latina seja a líder de crescimento mundial, com o Brasil acima da média do continente (Euromonitor, 2020).

Essas mudanças no Brasil seguem uma tendência mundial de mercado em crescimento, e a formação de mercados exige um duplo movimento: a refutação da oposição moral que impede a circulação de determinado bem (Radin, 1996) e a moralização da própria prática de mercado (Sen, 1985). Na verdade, o mercado da estética masculina implica uma redefinição do conceito de masculinidade (Connell, 2014), mesmo que esses consumidores busquem permanentemente sua diferenciação em relação ao gênero feminino (Elliot; Elliot, 2005; Fontes; Borelli; Cassoti, 2012).

Analisar a lógica de formação de um mercado unicamente pelas lentes do interesse próprio mostrou-se bastante limitada (Bajde, 2006), uma vez que o comportamento do consumidor está inserido nas relações sociais típicas de contextos específicos (Frenzen; Davis, 1990; Dimaggio; Louch, 1998). Portanto, o presente estudo pretende contribuir para a análise de como as variáveis associadas ao interesse próprio são moderadas pela lógica das interações sociais.

Para compreender a formação da intenção do consumidor, a literatura tem enfatizado o papel da indulgência (Wiggin; Reimann; Jain, 2019), da vaidade (Abdala, 2008; Strehlau; Claro; Abraão Neto, 2015), suscetibilidade à influência interpessoal (Netemeyer; Bearden; Teel, 1992; Kropp; Lavack; Silvera, 2005) e da necessidade de pertencimento (Baumeister; Leary, 1995). Este estudo sugere um modelo analítico que integra esses diferentes aspectos a partir do pressuposto de que as variáveis individuais são moderadas pelas interações sociais dos indivíduos na formação de sua intenção de consumo.

Reconhecendo que os mercados são construções sociais e que também são formados por interesses, investiga-se a relação entre o comportamento da parte interessada (microssocial) e a intenção de consumo para compreender a formação do mercado estético masculino. A maioria dos estudos clássicos e seminais sobre a formação do mercado enfatiza a lógica macrossocial 
entre os atores econômicos manifestada na literatura da sociologia econômica (Granovetter, 1973; Durkheim, 1975; Polanyi, 2000).

Por outro lado, poucos são os estudos empíricos que discutem a formação de mercados sob a lógica microssocial e individual, enfatizando o comportamento do interessado. O estudo que mais se aproxima dessa lógica e que considera a subjetividade dos agentes econômicos e suas peculiaridades é a pesquisa de Abramovay (2004). Os estudos disponíveis enfatizam a questão sob a ótica do comportamento feminino, principalmente, no que se refere ao conteúdo emocional envolvido nas atitudes do consumidor.

Considerando indulgência, vaidade, susceptibilidade à influência interpessoal e necessidade de pertencimento como influenciadores de comportamento, bem como a abertura global dos mercados e o surgimento de novos padrões de consumo, é importante analisar se essas variáveis influenciam na intenção de consumo do consumidor, indivíduo interessado. E também verificar se contribuem para a formação do mercado da estética masculina. Essa avaliação pode trazer importantes contribuições teóricas para a literatura de marketing e formação de mercado.

O contexto brasileiro é relevante para a análise do tema, uma vez que há um fenômeno de crescimento em espaços exclusivos para atendimento ao público masculino, como salões de beleza customizados, além do crescimento do consumo de produtos por esse público específico.

\section{Base teórica}

\section{Indulgência e vaidade}

Indulgência significa "mimar-se", ceder ao desejo, permitir-se presentear, o que muitas vezes envolve o ato de gastar em itens percebidos como luxo, como álibis (desculpas) em que os indivíduos confiam para fazer algo que não é uma prática comum, mas, por meio da autopercepção do mérito (“Eu mereço!”), torna-se aceitável (Kivetz; Simonson, 2002).

No contexto da escolha do consumidor, indulgência é como se permitir escolher e desfrutar do prazer de uma opção que é considerada um deleite em relação às opções alternativas (Berry, 1994; Prinsen; Evers; de Ridder, 2019), para se consolar diante de alguma insatisfação ou se recompensar após atingir algum objetivo (Xu, Schwarz, 2009). Portanto, as pessoas podem fazer escolhas indulgentes em toda uma gama de domínios de consumo (alimentos, viagens, roupas, cuidados pessoais), que podem incluir os melhores ingredientes a um custo mais alto (Cavanaugh, 2014). 
Os consumidores encontraram na indulgência uma forma de terapia para questões rotineiras, com o intuito de melhorar o humor ou buscar prazer (Clarke; Mortimer, 2013). Encarar a indulgência como tendência é entender que o consumidor pode e deseja desenvolver novos hábitos e gostos, pois o poder da indulgência supera as restrições de saúde, financeiras e de tempo; tudo é voltado para o prazer e a autopercepção de merecimento (Kivetz; Simonson, 2002).

Hipótese 1: A indulgência influencia positivamente a intenção de consumir produtos estéticos masculinos.

Por outro lado, a vaidade tem se mostrado um importante preditor do comportamento do consumidor, considerada como um construto psicológico que indica a preocupação do indivíduo com sua própria aparência física, influenciada por padrões estéticos culturalmente edificados (wang; Waller, 2006; Strehlau; Claro; Abrahão Neto, 2015).

A vaidade está associada ao cuidado de si, muitas vezes associada à beleza e à saúde (Strehlau; Claro; Abrahão Neto, 2015). Também pode ser considerada como uma necessidade saudável de melhorar a autoestima e o bem-estar, como uma espécie de passaporte para a felicidade, o sucesso e todas as outras coisas positivas na vida (Wang, Waller, 2006). As imagens de marketing estabelecem uma conexão com a vaidade do consumidor para diferentes bens e serviços, como perfumes, artigos de moda, carros de luxo, produtos diet, cirurgias e cosméticos (Wang, Waller, 2006).

A vaidade tem se mostrado um importante preditor da autoconsciência do consumidor (Lee, Workman, 2014) e da autoimagem (Sedikides et al., 2007; Ye; Robetson, 2012), sendo os vaidosos mais suscetíveis aos esforços de marketing (Watson et al., 1999), dispostos a gastar mais com cuidados pessoais (Wang, Waller, 2006). Portanto, quanto maior a vaidade física, maior o consumo de produtos e serviços estéticos (Abdala, 2008). A vaidade pode afetar o consumo de cosméticos e tratamentos, a frequência dos cuidados cosméticos e o envolvimento do indivíduo com a beleza (Strehlau; Claro; Abrahão Neto, 2015).

Assim, considerando-se que o consumo de produtos estéticos pelo público masculino pode ser uma forma de indulgência, vista como prática de autorrealização, e os produtos e serviços de beleza podem ser pensados pelo simbolismo que representam, além de sua tangibilidade, é lógico supor que a indulgência influencia positivamente a formação do interesse masculino pelo mercado estético.

Da mesma forma, é possível considerar que a necessidade de se sentir atraente e a busca por se sentir bem consigo mesmo podem influenciar de maneira positiva a intenção de consumir 
produtos estéticos que permitam melhorar a aparência, de acordo com padrões sociais e estéticos preestabelecidos.

Tendo em conta a literatura existente sobre a influência da indulgência e da vaidade no consumo de produtos estéticos, surgem as seguintes hipóteses na tentativa de compreender a intenção de consumo no mercado específico da estética masculina:

Hipótese 2: A vaidade influencia positivamente a intenção de consumir produtos estéticos masculinos.

\section{Suscetibilidade à influência interpessoal e necessidade de pertencimento}

Frequentemente, os indivíduos mudam seus padrões de consumo motivados por pressões sociais (Netemeyer; Bearden; Teel, 1992; Kropp; Lavack; Silvera, 2005). Essas pressões sociais foram chamadas de suscetibilidade do consumidor à influência interpessoal (Mcguire, 1968).

Netemeyer, Bearden e Tell (1992) apontam que a influência interpessoal é um fator importante que determina o comportamento do consumidor, o qual considera os valores e as atitudes de outras pessoas ou grupos de referência com os quais se identifica, para definir suas opções de consumo. Portanto, a suscetibilidade do consumidor à influência interpessoal é considerada uma característica subjetiva do indivíduo, um traço de personalidade, ou seja, cada sujeito tem sua própria capacidade de responder à influência social (Netemeyer; Bearden; Teel, 1992).

Influência interpessoal é definida como a necessidade de identificar ou melhorar a própria imagem a partir da opinião alheia, por meio da compra e uso de produtos e marcas, e está relacionada aos valores individuais, ou seja, cognições sociais de alto nível que modelam as atitudes dos consumidores, comportamentos e autoestima, uma medida de identidade social ou coletiva (Kropp; Lavack; Silvera, 2005).

Sujeitos mais suscetíveis à influência interpessoal têm escolhas e decisões de consumo que dão mais relevância às opiniões de outros consumidores do que às suas próprias características ou motivações. Eles valorizam a necessidade de pertencer, o relacionamento afetuoso com os outros e acreditam que serão mais respeitados do que aqueles que são menos suscetíveis à influência interpessoal (Kropp et al., 2000) e, portanto, estão mais propensos a adquirir produtos que considerem mais capazes de melhorar sua imagem aos olhos dos outros (Netemeyer; Bearden, Teel, 1992). 
Estudos revelam que a escolha por marcas de luxo é influenciada por grupos de referência que fazem parte de relacionamentos próximos (Escalas; Bettman, 2005; Shukla, 2011) ou externos (Escalas; Bettman, 2005; Berger; Heath, 2007). Indicam também que os significados associados ao consumo de grupos de referência ajudam os indivíduos a criar suas próprias identidades (Mccracken, 1989), tornando a suscetibilidade à influência interpessoal um preditor da necessidade de exclusividade (Nabi; O'cass; Siahtiri, 2019) ou até mesmo como estratégia para evitar a rejeição social (Lee; Shrum, 2012).

Com base nessas evidências, este estudo postula se a suscetibilidade à influência interpessoal pode moderar a relação entre as variáveis indulgência e vaidade na formação da intenção de consumir produtos estéticos masculinos. Essa lógica é expressa nas seguintes hipóteses:

Hipótese 3a: A suscetibilidade à influência interpessoal modera a relação entre indulgência e a intenção de consumir produtos estéticos masculinos, e a relação entre indulgência e intenção de consumo será mais fraca dependendo do aumento da suscetibilidade à influência interpessoal.

Hipótese 3b: A suscetibilidade à influência interpessoal modera a relação entre vaidade e intenção de consumir produtos estéticos masculinos, e a relação entre vaidade e intenção de consumo será mais fraca dependendo do aumento da suscetibilidade à influência interpessoal.

Associada à suscetibilidade a influências externas, a necessidade de pertencimento também pode ser entendida a partir de uma orientação fundamental das relações interpessoais. Schutz (1966) indica três necessidades básicas subjacentes ao comportamento coletivo das pessoas: inclusão, referente à necessidade de pertencer ou incluir outras pessoas em um círculo de conhecidos; afeto ou necessidade de amar ou ser amado pelos outros; e controle, que inclui a necessidade de exercer poder sobre outros ou empoderar outros (Schutz, 1966).

Para estabelecer e manter relacionamentos sociais, os indivíduos devem ser sensíveis aos pensamentos e sentimentos dos outros. As pessoas precisam ser amadas e aceitas socialmente, e esse fenômeno é conhecido como necessidade de pertencer (Baumeister; Leary, 1995; Leary et al., 2013; Leary; Baumeister, 2017). Essa necessidade de pertencimento do ser humano é uma motivação humana crucial, algo que todo ser humano deve estabelecer e manter pelo menos um mínimo de relações interpessoais duradouras, positivas e significativas (Baumeister; Leary, 1995). 
A necessidade de pertencimento força o indivíduo a tomar decisões com base no desejo de formar conexões interpessoais, e não em fatores intrínsecos (Pickett; Gardner; Knowles, 2004). Indivíduos com maior necessidade de pertencer temem ser excluídos e estão mais preocupados com a conectividade social do que aqueles com menos necessidade de pertencer (Baumeister; Leary, 1995).

Estudos revelam que consumidores com alta necessidade de pertencimento tendem a se apropriar do simbolismo da marca quando ele é endossado por celebridades, influenciando na busca por relações parassociais com celebridades e mediando a relação entre endosso e marca. Isso sugere a necessidade de pertencimento como indicador de preocupação em relação à identidade social do consumidor (Escalas; Bettman, 2017). Estudos também indicam que a necessidade de pertencimento está associada à antropomorfização (Epley et al., 2008) e ao engajamento com o comportamento positivo da equipe, mostrando-se como moderador da relação entre a marca e o boca a boca positivo (Sicilia; Delgado-Ballester; Palazon, 2016).

A partir deste referencial teórico, esta pesquisa postula se a necessidade de pertencimento tem ou não um efeito moderador nas relações entre indulgência, vaidade e intenção de consumir produtos estéticos masculinos. Especificamente, acredita-se que níveis mais elevados de necessidade de pertencimento levarão o indivíduo a relegar aspectos mais egoístas (indulgência e vaidade) à tomada de decisão. Portanto, uma maior necessidade de pertencimento enfraquecerá o papel da indulgência e da vaidade na formação do mercado de produtos estéticos masculinos. Em contrapartida, quanto menor a necessidade de pertencimento dos indivíduos, maior a relevância da indulgência e da vaidade para o estabelecimento desse mercado. Essa lógica é apresentada nas seguintes hipóteses:

Hipótese 4a: A necessidade de pertencimento modera a relação entre indulgência e a intenção de consumir produtos estéticos masculinos, e a relação entre indulgência e intenção de consumo será mais fraca dependendo do aumento da necessidade de pertencimento.

Hipótese 4b: A necessidade de pertencimento modera a relação entre vaidade e intenção de consumir produtos estéticos masculinos, e a relação entre vaidade e intenção de consumo será mais fraca dependendo do aumento da necessidade de pertencer. Com base nas hipóteses de pesquisa, o modelo teórico é apresentado na Figura 1. 
Figura 1 - Modelo Teórico

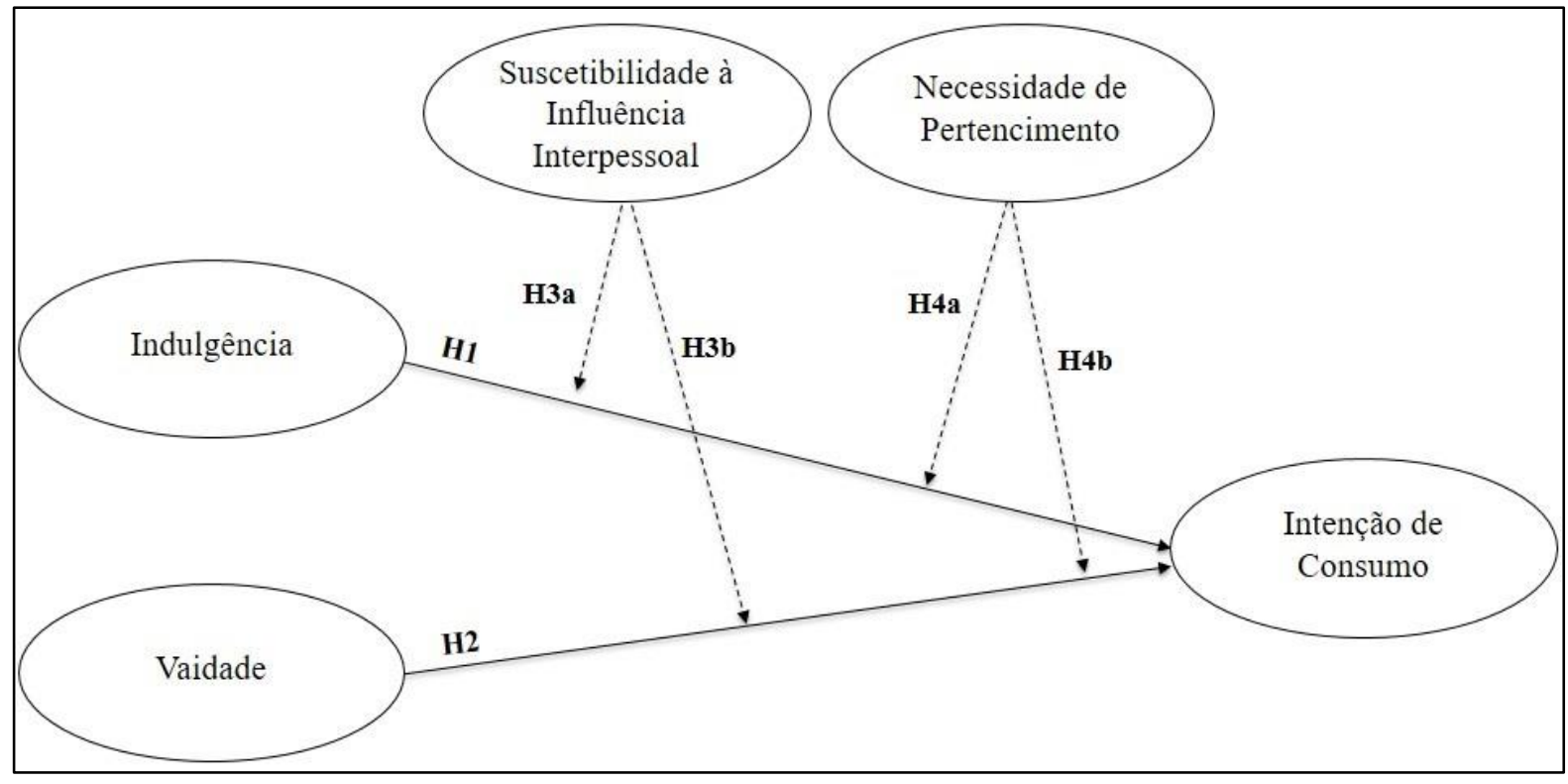

Fonte: Elaborada pelos autores (2017).

\section{Método}

Levando em consideração a questão de pesquisa e os objetivos traçados neste estudo, o tipo de abordagem mais adequada é a quantitativa, descritiva, transversal, operacionalizada por meio de uma Survey.

Os participantes que fizeram parte da amostra desta pesquisa, todos do sexo masculino, maiores de 18 anos, foram recrutados a partir de uma lista de contatos. A amostra foi composta por 377 casos, acessados por amostragem por conveniência. A pesquisa foi operacionalizada por meio de questionário disponibilizado de modo on-line na plataforma Qualtrics.

Para determinar o tamanho mínimo da amostra, foi respeitada a regra de utilizar pelo menos 10 respondentes para cada variável observável (Hair et al., 2005) ou, pelo menos, 200 respondentes (Kline, 2005). Com base nesses parâmetros, a amostra calculada é de, pelo menos, 290 casos (29 questões multiplicadas por 10 respondentes). Assim, obteve-se uma amostra de 377 casos válidos, acessados de forma não probabilística ou por conveniência, devido à técnica utilizada e à facilidade de acesso do pesquisador.

As medidas utilizadas nesta pesquisa foram adaptadas de outros estudos: i) escala de indulgência (Clarke; Mortimer, 2013); ii) vaidade (Netemeyer; Burton; Lichtenstein, 1995); iii) escala de suscetibilidade à influência interpessoal (Consumer Susceptibility to Interpersonal Influence - SUSCEP) (Bearden; Netemeyer; Teel, 1989); iv) necessidade de pertencimento (Need to Belong Scale) de Leary et al. (2013) e v) intenção de consumo (Bruner; Hensel, 1998). 
Todas as medidas utilizadas estão incluídas no apêndice, juntamente com a confiabilidade de cada escala.

Ao final do questionário foram apresentadas algumas questões relacionadas ao consumo, como o tipo de intenção de consumo, comportamento anterior, frequência de consumo e, por último, a caracterização sociodemográfica dos respondentes.

Antes da coleta de dados, foi realizado um pré-teste com 13 (treze) indivíduos pertencentes ao grupo de respondentes do escopo da pesquisa. Este procedimento foi realizado para verificar a clareza dos termos do formulário. Pequenas mudanças no fluxo do instrumento foram aplicadas para simplificar a coleta de dados.

Após a coleta, os dados foram tratados por meio do software Statistical Package for Social Sciences® (SPSS). Antes da análise dos dados, verificou-se que não há multicolinearidade entre os construtos, uma vez que a maior correlação bivariada é entre suscetibilidade à influência interpessoal e necessidade de pertencimento $(r=0,59 ; p<0,01)$. Além disso, há homocedasticidade ao longo das variâncias, verificada através do teste de Levene, boxplot e análise gráfica dos resíduos.

Para análise dos dados, cada construto compreendeu a média dos indicadores correspondentes (uma análise comparativa compreendendo os construtos com o escore fatorial não alterou os resultados apresentados). Utilizaram-se dois procedimentos para testar o modelo teórico apresentado na Figura 1. Para o teste das hipóteses $\mathrm{H} 1$ e H2, foi utilizado um modelo de regressão linear múltipla (mínimos quadrados ordinários), enquanto para o teste das hipóteses de moderação (H3a, H3b, H4a, H4b) foi utilizado o script MODPROBE (Hayes; Matthes, 2009), com a técnica de Johnson-Neyman (Johnson; Fay, 1950) para identificar as áreas de significância da relação, com base nos níveis da variável moderadora. $\mathrm{O}$ script MODPROBE usado é baseado na análise de regressão de mínimos quadrados ordinários. Este script regrediu a variável dependente pela variável independente, a variável moderadora e o termo de interação (variável independente $X$ variável moderadora).

\section{Resultados}

\section{Perfil da amostra}

Quanto à idade dos respondentes, detecta-se uma predominância de faixa etária entre 26 a 35 anos (50,7\%); a idade média dos participantes foi de 32,5 ( $\sigma=8,52$ anos); a maioria é solteiro (46\%), e o nível de instrução majoritário foi pós-graduação. 
Com o intuito de medir em que nível os indivíduos abordados pretendem ou não consumir produtos estéticos, além da operacionalização do construto "intenção de consumo", cuja base de escala foi a de Bruner e Hensel (1998), levantou-se uma questão de múltipla escolha sobre que tipo de consumo melhor configuraria essa intenção. A questão dividia em três grupos o tipo de consumo: o primeiro grupo dava escolha para aqueles que pretendem consumir um cosmético, um hidratante facial, por exemplo; o segundo, para aqueles que pretendem consumir algo mais invasivo, como uma cirurgia plástica para fins estéticos; por último, uma opção para aqueles que não pretendem consumir. Dos participantes da pesquisa, 47,7\% têm intenção de consumir um produto estético como um hidratante facial; já em um procedimento mais invasivo como uma cirurgia plástica, apenas 13\% se mostrou interessado; o percentual de quem não tem intenção de consumir esse tipo de produto ou serviço foi de $39,3 \%$.

Ainda com foco na intenção de consumo, os entrevistados foram questionados sobre a utilização de serviços prestados em salões de beleza, barbearias e clínicas de estética para realização de tratamentos estéticos além do corte de cabelo, e 59\% disseram que não, que não utilizam outros serviços nesses espaços.

\section{Teste das hipóteses $\mathrm{H1}$ e $\mathrm{H} 2$}

Para o teste das hipóteses H1 e H2, o modelo de regressão linear múltipla considerou indulgência e vaidade como variáveis independentes, e a intenção de consumo como variável dependente. Especificamente, os resultados do modelo indicam que a indulgência $(\beta=0,454 ; \mathrm{t}$ $=6,472 ; \mathrm{p}<0,001)$ e a vaidade $(\beta=0,414 ; \mathrm{t}=6,472 ; \mathrm{p}<0,001)$ têm um efeito positivo na intenção de consumo de produtos estéticos masculinos. Esses achados sustentam as hipóteses $\mathrm{H} 1$ e H2, assim como sustentam a premissa de que tanto a indulgência quanto a vaidade são fatores importantes para o estabelecimento desse mercado.

Além disso, com base nesses dois antecedentes (indulgência e vaidade), o modelo explica $31 \%$ das variações da intenção de consumo $\left(R^{2}=0,310\right)$. A equação (1) apresenta a relação entre vaidade e indulgência como preditores da intenção de consumir produtos estéticos.

$$
\gamma=0,684+0,454 * \text { Indulgência }+0,414 * \text { Vaidade }+\varepsilon
$$




\section{Teste das hipóteses H3a, H3b, H4a e H4b}

Inicialmente, para testar as hipóteses $\mathrm{H} 3 \mathrm{a}$ e $\mathrm{H} 3 \mathrm{~b}$, a suscetibilidade à influência interpessoal foi considerada a variável moderadora, enquanto a indulgência (H3a) ou a vaidade (H3b) foram vistas como os preditores focais. Deve-se enfatizar que, quando a indulgência (vaidade) foi considerada como preditor focal da intenção de consumo, a vaidade (indulgência) também foi mantida como um preditor adicional no modelo, preservando-se as configurações do modelo mostradas na equação 1 .

No teste da H3a, houve um efeito positivo de ambas na intenção de consumo: indulgência $(\beta=0,852 ; \mathrm{t}=4,496 ; \mathrm{p}<0,001)$ e vaidade $(\beta=0,339 ; \mathrm{t}=5,452 ; \mathrm{p}<0,001)$. A suscetibilidade à influência interpessoal também apresentou um efeito positivo na intenção de consumo $(\beta=0,780 ; t=3,474 ; p<0,001)$. Mais importante foi a verificação de que há um efeito significativo da interação entre indulgência e suscetibilidade à influência interpessoal sobre a intenção de consumir produtos estéticos $(\beta=-0,119 ; \mathrm{t}=-2,586 ; \mathrm{p}<0,05)$. O efeito dessa moderação é mostrado na Figura 2, apresentando também o nível de suscetibilidade em que a influência interpessoal da relação entre indulgência e intenção de consumo não é mais significativa. Os resultados apresentados permitem a aceitação de H3a.

Figura 2 - Moderação da suscetibilidade à influência interpessoal na relação entre indulgência e intenção de consumo

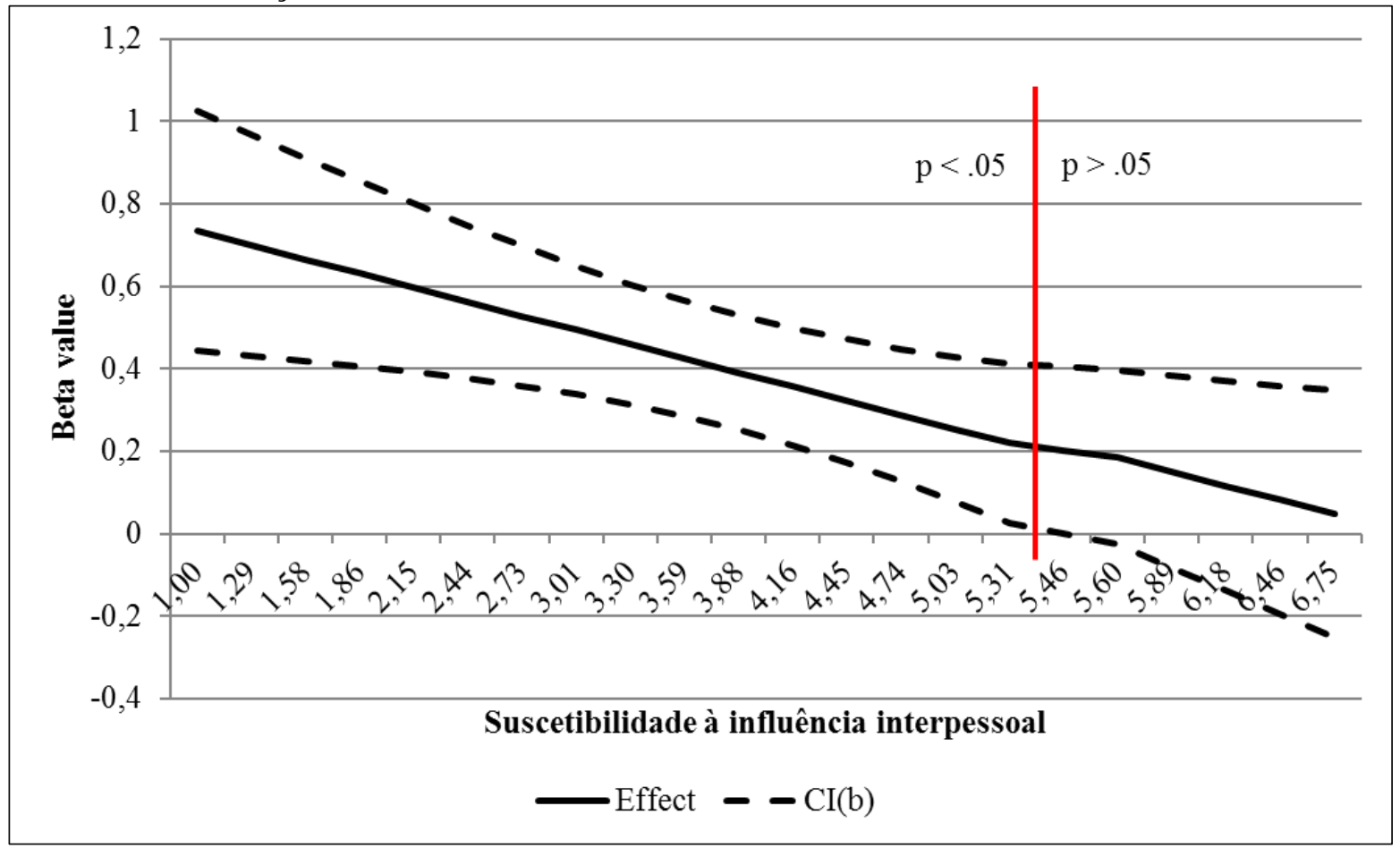

Fonte: Dados da pesquisa (2017). 
Conforme apresentado na Figura 2, a relação entre indulgência e intenção de consumo é significativa para níveis de suscetibilidade à influência interpessoal inferior a 5,45. Portanto, quando os indivíduos apresentam altos níveis de suscetibilidade à influência interpessoal (maior que 5,45 em uma escala de 7 pontos), a indulgência deixa de ser um importante preditor da intenção de consumo. Pode-se inferir também que, à medida que aumentam os níveis de suscetibilidade à influência interpessoal, o efeito da indulgência sobre a intenção de consumo é reduzido.

Assim como no teste de $\mathrm{H} 3 \mathrm{a}$, no teste da $\mathrm{H} 3 \mathrm{~b}$, verificou-se que há um efeito positivo tanto da indulgência $(\beta=0,392 ; \mathrm{t}=5,659 ; \mathrm{p}<0,001)$ quanto da vaidade $(\beta=0,874 ; \mathrm{t}=5,801$; $\mathrm{p}<0,001)$ na intenção de consumo. A suscetibilidade a influência interpessoal também apresentou um efeito positivo sobre a intenção de consumo $(\beta=0,945 ; \mathrm{t}=4.730 ; \mathrm{p}<0,001)$. Mais importante: há um efeito significativo da interação entre a vaidade e a suscetibilidade a influência interpessoal na intenção de consumo de produtos estéticos masculinos ( $\beta=-0,142$; $\mathrm{t}=-3,788 ; \mathrm{p}<0,001)$. O efeito desta moderação é apresentado na Figura 3, a qual também apresenta em que nível de suscetibilidade da influência interpessoal a relação entre a vaidade a intenção de consumo deixa de ser significante.

Figura 3 - Moderação da suscetibilidade a influência interpessoal na relação entre vaidade e intenção de consumo

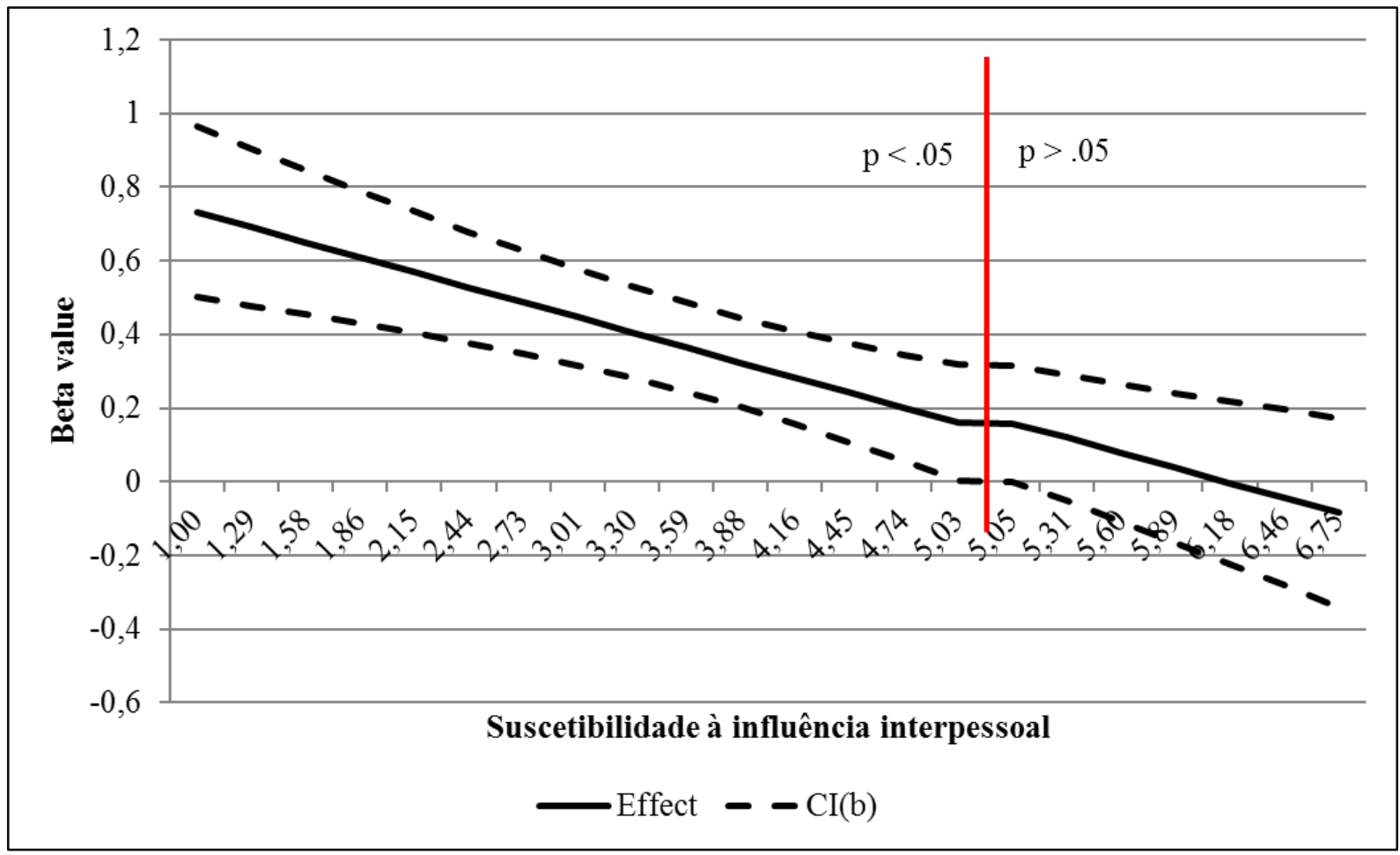

Fonte: Dados da pesquisa (2017). 
De acordo com o apresentado na Figura 3, a relação entre vaidade e intenção de consumo é significativa para níveis de suscetibilidade à influência interpessoal menores que 5,05. Dessa forma, quando os sujeitos possuem altos níveis de suscetibilidade à influência interpessoal (maior que 5,05 em uma escala de 7 pontos), o efeito da vaidade sobre a intenção de consumo deixa de ser significativo, e a vaidade passa a não ser um preditor importante para a construção do mercado de produtos estéticos masculinos. Esses resultados oferecem suporte a H3b.

Para o teste das hipóteses $\mathrm{H} 4 \mathrm{a}$ e $\mathrm{H} 4 \mathrm{~b}$, a necessidade de pertencimento foi considerada como a variável moderadora, enquanto que a indulgência (H4a) ou a vaidade (H4b) foram consideradas como os preditores focais.

No teste de $\mathrm{H} 4 \mathrm{a}$, tanto a indulgencia $(\beta=0,885 ; \mathrm{t}=4,224 ; \mathrm{p}<0,001)$ quanto a vaidade $(\beta=0,344 ; t=5,478 ; p<0,001)$ apresentaram efeitos positivos e significativos sobre a intenção de consumo. A necessidade de pertencimento, enquanto variável moderadora, também apresentou um efeito positivo sobre a intenção de consumo $(\beta=0,707 ; \mathrm{t}=3,072 ; \mathrm{p}<0,001)$. $\mathrm{O}$ efeito da interação entre a indulgência e a necessidade de pertencimento sobre a intenção de consumo de produtos estéticos masculinos foi significativo $(\beta=-0,113 ; \mathrm{t}=-2,362 ; \mathrm{p}<0.05)$. A Figura 4 apresenta os resultados desta interação que suportam a hipótese H4a.

Figura 4 - Moderação da necessidade de pertencimento na relação entre indulgência e intenção de consumo

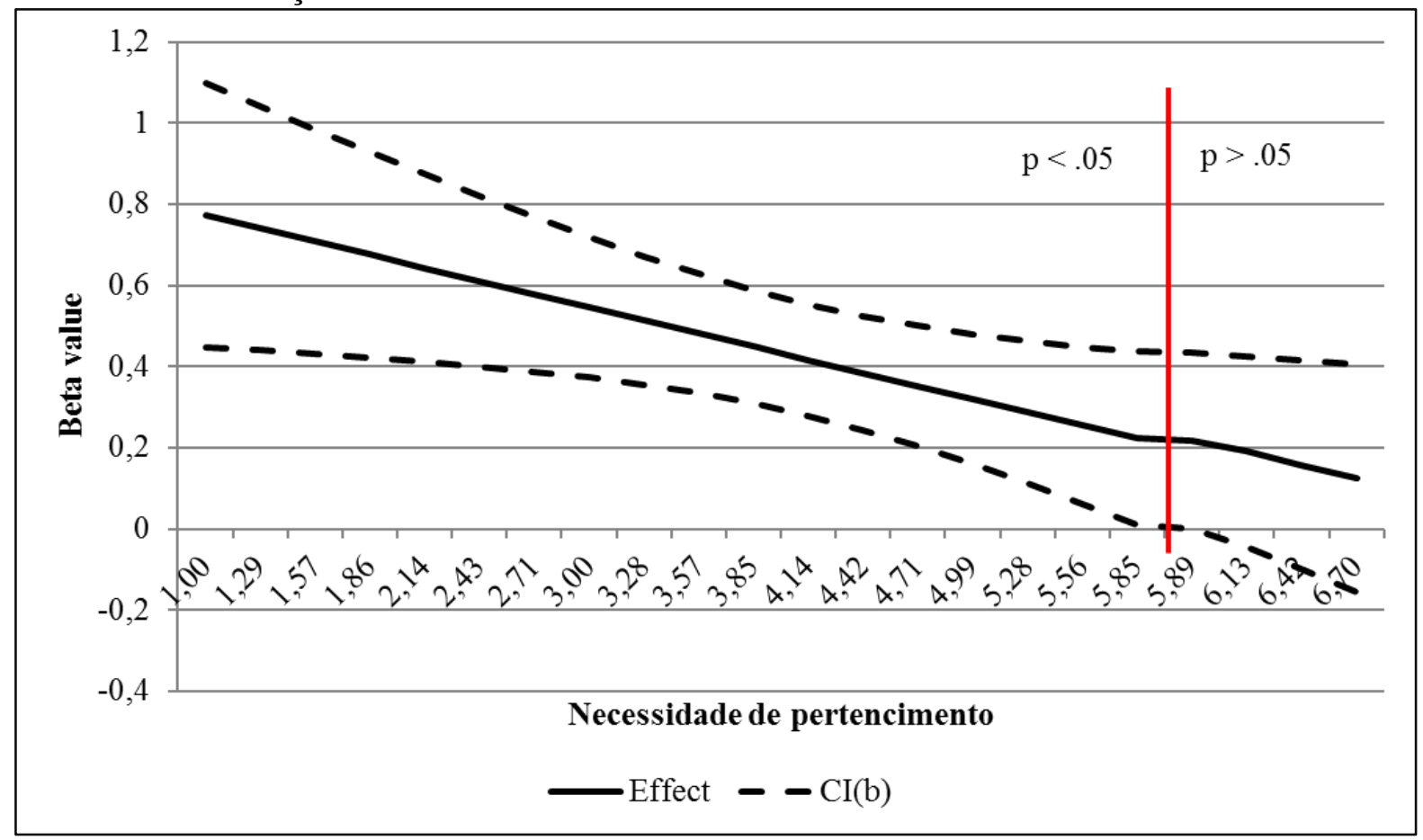

Fonte: Dados da pesquisa (2017). 
Os resultados provenientes do teste Johnson-Neyman, reproduzidos na Figura 4, indicam que a relação entre indulgência e intenção de consumo é significativa para níveis de necessidade de pertencimento menores que 5,89. Dessa forma, o aumento da necessidade de pertencimento, enquanto um traço individual, reduz a influência que a indulgência possui na intenção de consumir produtos estéticos masculinos.

Por fim, no teste de H4b, tanto a indulgência $(\beta=0,420 ; \mathrm{t}=6,149 ; \mathrm{p}<0,001)$ quanto a vaidade $(\beta=1,026 ; \mathrm{t}=6,514 ; \mathrm{p}<0,001)$ apresentaram efeitos positivos e significativos sobre a intenção de consumo. A necessidade de pertencimento, enquanto variável moderadora, também apresentou um efeito positivo sobre a intenção de consumo $(\beta=1,084 ; \mathrm{t}=5,294 ; \mathrm{p}<0,001)$. O efeito da interação entre a vaidade e a necessidade de pertencimento sobre a intenção de consumo de produtos estéticos masculinos foi significativo $(\beta=-0,177 ; \mathrm{t}=-4,579 ; \mathrm{p}<0,001)$.

A Figura 5 apresenta os resultados dessa interação.

Figura 5 - Moderação da necessidade de pertencimento na relação entre vaidade e intenção de consumo

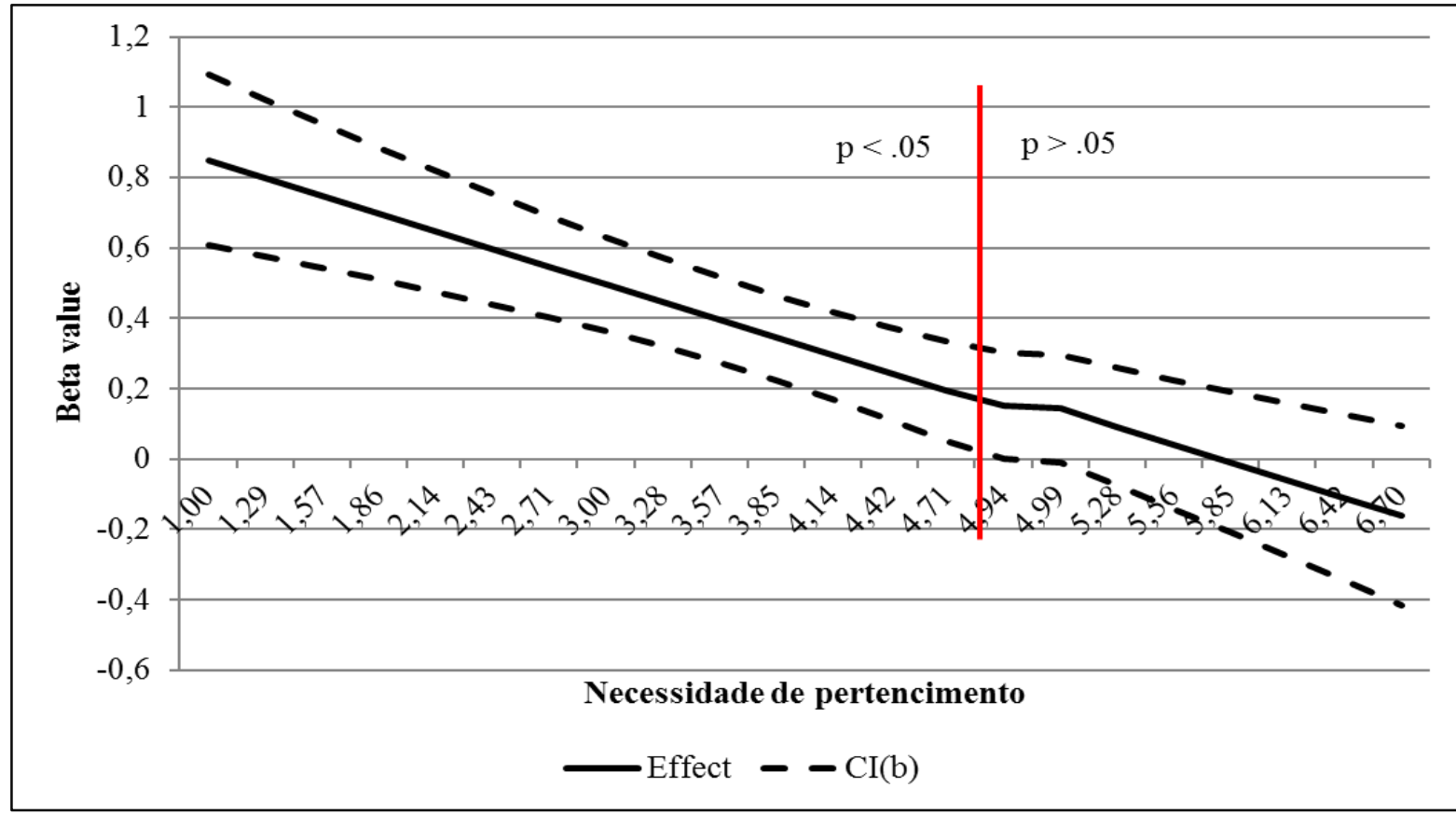

Fonte: Dados da pesquisa (2017).

De acordo com o apresentado na Figura 5, a relação entre vaidade e intenção de consumo é significativa para níveis de necessidade de pertencimento menores que 4,94. Desse modo, o aumento da necessidade de pertencimento, enquanto um traço individual, reduz a influência que a vaidade possui na intenção de consumir produtos estéticos masculinos. Essses achados suportam a Hipótese H4b. 
Assim, com base no estudo do modelo integrado teórico e dos índices de ajuste do modelo para analisar as medidas de ajuste absoluto sugeridos por Hair et al. (2009), chegou-se ao resultado final das hipóteses levantadas (Quadro 1).

Quadro 1 - Síntese dos resultados da pesquisa

\begin{tabular}{|l|l|}
\hline \multicolumn{2}{|c|}{ Hipóteses de pesquisa } \\
\hline $\begin{array}{l}\text { H1 - A indulgência influencia positivamente a intenção de consumo de produtos } \\
\text { estéticos masculinos }(\beta=0,454 ; \mathrm{t}=6,472 ; \mathrm{p}<0,001) .\end{array}$ & Não rejeitada \\
\hline $\begin{array}{l}\text { H2 - A vaidade influencia positivamente a intenção de consumo de produtos estéticos } \\
\text { masculinos }(\beta=0,414 ; \mathrm{t}=6,472 ; \mathrm{p}<0,001) .\end{array}$ & Não rejeitada \\
\hline $\begin{array}{l}\text { H3a - A suscetibilidade à influência interpessoal modera a relação entre a indulgência e } \\
\text { a intenção de consumo de produtos estéticos masculinos, sendo que a relação entre } \\
\text { indulgência e intenção de consumo será mais fraca de acordo com o aumento da } \\
\text { suscetibilidade à influência interpessoal }(\beta=-0,119 ; \mathrm{t}=-2,586 ; \mathrm{p}<0,05) .\end{array}$ & Não rejeitada \\
\hline $\begin{array}{l}\text { H3b - A suscetibilidade à influência interpessoal modera a relação entre a vaidade e a } \\
\text { intenção de consumo de produtos estéticos masculinos, sendo que a relação entre } \\
\text { vaidade e intenção de consumo será mais fraca de acordo com o aumento da } \\
\text { suscetibilidade à influência interpessoal }(\beta=-0,142 ; \mathrm{t}=-3,788 ; \mathrm{p}<0,001) .\end{array}$ & Não rejeitada \\
\hline $\begin{array}{l}\text { H4a - A necessidade de pertencimento modera a relação entre a indulgência e a intenção } \\
\text { de consumo de produtos estéticos masculinos, sendo que a relação entre indulgência e } \\
\text { intenção de consumo será mais fraca de acordo com o aumento da necessidade de } \\
\text { pertencimento }(\beta=-0,113 ; \mathrm{t}=-2,362 ; \mathrm{p}<0.05) .\end{array}$ & Não rejeitada \\
\hline $\begin{array}{l}\text { H4b - A necessidade de pertencimento modera a relação entre a vaidade e a intenção de } \\
\text { consumo de produtos estéticos masculinos, sendo que a relação entre vaidade e intenção } \\
\text { de consumo será mais fraca de acordo com o aumento da necessidade de pertencimento } \\
(\beta=-0,177 ; \mathrm{t}=-4,579 ; \mathrm{p}<0,001) .\end{array}$ & Não rejeitada \\
\hline
\end{tabular}

Fonte: Elaborado pelos autores (2017).

\section{Discussão}

O estudo testou o modelo com as variáveis indulgência e vaidade como precedentes da construção do mercado de produtos estéticos masculinos (H1 e H2). Os resultados revelam que tanto a indulgência quanto a vaidade são fatores importantes para formação deste mercado.

No âmbito acadêmico, essa confirmação vai ao encontro de proposições teóricas que sugerem que a indulgência influencia a intenção de consumo (Xu; Schwarz, 2009; Petersen, 2012; Cavanaugh; 2014), no sentido que o consolo e a recompensa são os grandes motivadores do consumo indulgente. E a vaidade, enquanto construção psicológica, é um fator que influencia a intenção de consumo (Bloch; Richins, 1992).

As hipóteses $3 \mathrm{a}$ e $3 \mathrm{~b}$ previam o efeito moderador da suscetibilidade à influência interpessoal entre a indulgência e a intenção de consumo e entre a vaidade e a intenção de 
consumo. A revisão de literatura sugeriu que as pessoas são suscetíveis à influência interpessoal nas questões de consumo (Netemeyer; Bearden; Teel, 1992).

Os resultados desse estudo confirmam as hipóteses H3a e H3b, indicando que a relação entre indulgência para a construção do mercado de produtos estéticos masculinos é condicionada pelo perfil dos atores deste mercado. Portanto, a importância da indulgência é maior quando os sujeitos não possuem tanta suscetibilidade à influência interpessoal, uma vez que o aumento dessa suscetibilidade diminui a importância da indulgência para a formação do mercado destes produtos. Da mesma forma, quando os sujeitos possuem altos níveis de suscetibilidade à influência interpessoal, a importância da vaidade para a construção do mercado de produtos estéticos masculinos deixa de ser significativa, e a vaidade passa a não ser um preditor importante.

As hipóteses $4 \mathrm{a}$ e $4 \mathrm{~b}$ previam o efeito moderador da necessidade de pertencimento entre a indulgência e a intenção de consumo e entre a vaidade e a intenção de consumo do consumidor, sendo estas relações mais fracas de acordo com o aumento da necessidade de pertencimento. A relação entre indulgência e intenção de consumo é significativa para níveis menores de necessidade de pertencimento, bem como na relação entre vaidade e intenção de consumo.

Desse modo, o aumento da necessidade de pertencimento reduz a influência que a indulgência e a vaidade possuem na intenção de consumir produtos estéticos masculinos, visto que a indulgência e a vaidade são características mais intrínsecas, e a necessidade de pertencimento remete ao coletivo, à conectividade social (Pickett; Gardner; Knowles, 2004). O indivíduo mais vaidoso não depende da necessidade de pertencer para consumir, visto que a vaidade se trata de uma característica mais individualista.

Featherstone (1991) já dava indícios da importância de se entender as variantes de conexão entre o consumidor e o produto, além de como são formadas e mantidas tais conexões. Seguindo essa mesma linha de raciocínio, levantou-se a questão desta pesquisa, envolvendo questões subjetivas e comportamentais no consumo e o entendimento dessas questões como determinantes para formação de mercados.

\section{Conclusão}

Espera-se que este estudo contribua para um melhor entendimento das influências exercidas pela indulgência e vaidade do consumidor na intenção de consumo e posterior constituição de um mercado, desencadeando novas discussões teóricas sobre o assunto. Da 
mesma forma, espera-se contribuir com os gestores empresariais para um melhor planejamento das estratégias de marketing e na difícil tarefa de compreender as características dos consumidores que influenciam as atitudes e o comportamento de compra.

Uma das contribuições deste estudo para a pesquisa acadêmica está na validação de um modelo teórico, o que ocorreu, com suporte estatístico e teórico. No estudo empírico, observouse que as principais relações envolvendo indulgência e vaidade na intenção de consumo estão fortemente relacionadas e que indulgência e vaidade são comportamentos de consumo que contribuem para a intenção de consumir produtos estéticos masculinos.

Quanto às contribuições gerenciais, este estudo trouxe informações importantes para direcionar as empresas para novas oportunidades de trabalho e definição de estratégias. Um novo perfil de consumidor está sendo desenvolvido; clientes diversificados e exigentes requerem profissionais especializados e estabelecimentos confiáveis. O empresário precisa estar atualizado e falar a mesma língua do público que pretende atingir. A conexão com o consumidor em nichos de mercado precisa ser muito mais intensa e direta.

Administradores que trabalham com produtos ou serviços estéticos voltados para o público masculino devem considerar a indulgência e todos os fatores emocionais a ela associados para organizar seus ambientes e desenhar uma campanha publicitária. Os empresários que pretendem entrar neste mercado em expansão devem considerar a indulgência como um componente essencial do comportamento do consumidor e pensar em seu negócio como um ambiente ou um produto para satisfazer um desejo que os consumidores, além do consumo físico, pretendem satisfazer seu prazer.

Movimentos globais apontam para macro e megatendências em que apelos mais rápidos, muito concretos, estão por toda parte e, na outra ponta, há uma forte sensibilidade para desacelerar e relaxar, o que parece anunciar novos comportamentos. Os consumidores buscam cada vez mais experiências sensoriais. Inspirar novas marcas, novos conceitos e empreendimentos, bem como criar novos produtos e serviços, ajudará a oferecer essas experiências aos consumidores. E experiências bem-sucedidas indicam diretrizes para o consumo consciente.

Tendências de bem-estar com olhar para a moda marcam uma visão nova e mais integral de como o setor da beleza pode proporcionar satisfação, bem-estar e saúde, pois, de acordo com estudos recentes, sabe-se que as escolhas e os comportamentos são os que mais impactam a felicidade, longevidade e saúde do que herança genética. 


\section{Referências}

ABDALA, P. R. Z. Vaidade e Consumo: Como a vaidade física influencia o comportamento do consumidor. Porto Alegre: UFRGS, 2008. Dissertação (Mestrado em Administração) Programa de Pós-Graduação em Administração da Universidade Federal do Rio Grande do Sul, Porto Alegre, RS, 2008.

BAJDE, D. Other-centered behavior and the dialectics of self and other. Consumption, Markets and Culture, v. 9, n. 4, p. 301-316, 2006. https://doi.org/10.1080/10253860600921845

BAUMEISTER, R. F.; LEARY, M. R. The need to belong: desire for interpersonal attachments as a fundamental human motivation. Psychological bulletin, v. 117, n. 3, p. 497, 1995. https://doi.org/10.1037/0033-2909.117.3.497

BEARDEN, W. O.; NETEMEYER, R. G.; TEEL, J. E. Measurement of consumer susceptibility to interpersonal influence. Journal of consumer research, p. 473-481, 1989. https://doi.org/10.1086/209186

BERGER, Jonah; HEATH, Chip. Where consumers diverge from others: Identity signaling and product domains. Journal of Consumer Research, v. 34, n. 2, p. 121-134, 2007. https://doi.org/10.1086/519142

BERRY, C. J. The Idea of Luxury. Cambridge, UK: Cambridge University Press, 1994.

BLOCH, P.; RICHINS, M. You look "mahvelous": the pursuit of beauty and the marketing concept. Journal of Psychology \& Marketing, v. 9, n. 1, p. 3-15, 1992. https://doi.org/10.1002/mar.4220090103

BRUNER, G.C. II; HENSEL, P. J. Marketing Scales Handbook: a Compilation of Multiitems Measures. Chicago: American Marketing Association, v. 2, 1998.

CAVANAUGH, L. A. Because I (don't) deserve it: How relationship reminders and deservingness influence consumer indulgence. Journal of Marketing Research, v. 51, n. 2, p. 218-232, 2014. https://doi.org/10.1509/jmr.12.0133

CLARKE, P. D.; MORTIMER, G. Self-gifting guilt: an examination of self-gifting motivations and post purchase regret. Journal of Consumer Marketing, v. 30, n. 6, p. 472483, 2013. https://doi.org/10.1108/JCM-05-2013-0566

CONNELL, R. The study of masculinities. Qualitative Research Journal, v. 14, n. 1, p. 5-15, 2014. https://doi.org/10.1108/QRJ-03-2014-0006

DE MOOIJ, M.; HOFSTEDE, G. Convergence and divergence in consumer behavior: implications for international retailing. Journal of retailing, v. 78, n. 1, p. 61-69, 2002. https://doi.org/10.1016/S0022-4359(01)00067-7

DIMAGGIO, P.; LOUCH, H. Socially embedded consumer transactions: For what kinds of purchases do people most often use networks? American sociological review, p. 619-637, 1998. https://doi.org/10.2307/2657331 
DURVASULA, S.; LYSONSKI, S. A double-edged sword: understanding vanity across cultures. Journal of Consumer Marketing, v. 25, n. 4, p. 230-244, 2008. https://doi.org/10.1108/07363760810882425

ELLIOTT, C.; ELLIOTT, R. Idealized Images of the Male Body in Advertising: A Reader Response Exploration. Journal of Marketing Communications, v. 11, n. 1, p. 3-19, 2005. https://doi.org/10.1080/1352726042000263566

EPLEY, N.; WAYTZ, A.; AKALIS, S.; CACIOPPO, J. T. When we need a human: Motivational determinants of anthropomorphism. Social cognition, v. 26, n. 2, p. 143-155, 2008. https://doi.org/10.1521/soco.2008.26.2.143

ESCALAS, J. E.; BETTMAN, J. R. Self-construal, reference groups, and brand meaning. Journal of consumer research, v. 32, n. 3, p. 378-389, 2005. https://doi.org/10.1086/497549

ESCALAS, J. E.; BETTMAN, J. R. Connecting with celebrities: how consumers appropriate celebrity meanings for a sense of belonging. Journal of Advertising, v. 46, n. 2, p. 297-308, 2017. https://doi.org/10.1080/00913367.2016.1274925

EUROMONITOR INTERNATIONAL, 2020. Disponível em: https://go.euromonitor.com/white-paper-beauty--personal-care-20-11-03-survey-keyfindings.html. Acesso em: 22 fev. 2021.

FEATHERSTONE, M. The body in consumer culture. In: FEATHERSTONE, M.; HEPWORTH, M.; TURNER, B. (Ed.). The Body - Social Process and Cultural Theory. London, pp.170-96, 1991. https://doi.org/10.1177/026327648200100203

FONTES, O. A.; BORELLI, F. C.; CASOTTI, L. M. Como ser homem e ser belo? Um estudo exploratório sobre a relação entre masculinidade e o consumo de beleza. REAd-Revista Eletrônica de Administração, v. 18, n. 2, 2012. https://doi.org/10.1590/S141323112012000200005

FRENZEN, J. K.; DAVIS, H. L. Purchasing behavior in embedded markets. Journal of Consumer Research, v. 17, n. 1, p. 1-12, 1990. https://doi.org/10.1086/208532

GARCIA, W. O Corpo contemporâneo: A Imagem do metrossexual no Brasil. Revista de Humanidades, v. 5, n. 11, 2004.

GARCIA, W. O metrossexual no Brasil: estudos contemporâneos. São Paulo: Factash Editora, 2011.

HAIR, J. F., BLACK, W. C., BABIN, B. J., ANDERSON, R. E., TATHAM, R. L. Análise multivariada de dados. Porto Alegre: Bookman, 6. ed, 2009.

HAYES, A. F.; MATTHES, J. Computational procedures for probing interactions in OLS and logistic regression: SPSS and SAS implementations. Behavior Research Methods, 41, 924936, 2009. https://doi.org/10.3758/BRM.41.3.924 
JOHNSON, P. O.; FAY, L. C. The Johnson-Neyman technique, its theory and application. Psychometrika, 15(4), 349-367, 1950. https://doi.org/10.1007/BF02288864

KIVETZ, R.; SIMONSON, I. Earning the right to indulge: Effort as a determinant of customer preferences toward frequency program rewards. Journal of Marketing Research, v. 39, n. 2, p. 155-170, 2002. https://doi.org/10.1509/jmkr.39.2.155.19084

KROPP, F.; JONES, M.; ROSE, G.; SHOHAM, A.; FLORENTHAL, B.; CHO, B. Group identities: A cross-cultural comparison of values and group influences. Journal of Euromarketing, v. 8, n. 1-2, p. 117-131, 2000. https://doi.org/10.4324/9781315865294-8

KROPP, F.; LAVACK, A. M.; SILVERA, D. H. Values and collective self-esteem as predictors of consumer susceptibility to interpersonal influence among university students. International Marketing Review, v. 22, n. 1, p. 7-33, 2005. https://doi.org/10.1108/02651330510581154

LEARY, M. R.; BAUMEISTER, R. F. The need to belong: Desire for interpersonal attachments as a fundamental human motivation. In: Interpersonal development. Routledge, 2017. p. 57-89. https://doi.org/10.1037/0033-2909.117.3.497

LEARY, M. R.; KELLY, K. M.; COTTRELL, C. A.; SCHREINDORFER, L. S. Construct validity of the need to belong scale: Mapping the nomological network. Journal of personality assessment, v. 95, n. 6, p. 610-624, 2013. https://doi.org/10.1080/00223891.2013.819511

LEE, J.; SHRUM, L. J. Conspicuous consumption versus charitable behavior in response to social exclusion: A differential needs explanation. Journal of Consumer Research, v. 39, n. 3, p. 530-544, 2012. https://doi.org/10.1086/664039

LEE, S.; WORKMAN, J. Vanity, fashion leadership, and self-consciousness among South Korean male and female college students. International Journal of Fashion Design, Technology and Education, v. 7, n. 2, p. 115-124, 2014. https://doi.org/10.1080/17543266.2014.903001

McGUIRE, W. J. Personality and susceptibility to social influence. Handbook of personality theory and research, v. 2, p. 1130-1187, 1968.

MILLAN, E.; WRIGHT, L. T. Gender effects on consumers' symbolic and hedonic preferences and actual clothing consumption in the Czech Republic. International Journal of Consumer Studies, v. 42, n. 5, p. 478-488, 2018. https://doi.org/10.1111/ijcs.12447

MOUNGKHEM, C.; SURAKIATPINYO, J. A study of factors affecting on men's skin care products purchasing, particularly in Karlstad, Sweden. 2010. 77f. Thesis. (Degree of Master of Business Administration School of Graduate Studies) - Karlstad University, Sweden.

NABI, N.; O'CASS, A.; SIAHTIRI, V. Status consumption in newly emerging countries: The influence of personality traits and the mediating role of motivation to consume conspicuously. Journal of Retailing and Consumer Services, v. 46, p. 173-178, 2019. https://doi.org/10.1016/j.jretconser.2017.09.009 
NETEMEYER, R. G.; BEARDEN, W. O., TEEL, J. E. Consumer susceptibility to interpersonal influence and atributional sensitivity. Psychology \& Marketing, Vol. 9, N.5, p. 379-394, 1992. https://doi.org/10.1002/mar.4220090504

NETEMEYER, R. G.; BURTON, S.; LICHTENSTEIN, D. R. Trait aspects of vanity:

Measurement and relevance to consumer behavior. Journal of consumer research, p. 612626, 1995. https://doi.org/10.1086/209422

PETERSEN, F. E. When do consumers indulge in luxury? Emotional certainty signals when to indulge to regulate affect. ESMT Working Paper, No. 12-06, 2012.

ttps://doi.org/10.2139/ssrn.2165197

PICKETT, C. L.; GARDNER, W. L.; KNOWLES, M. Getting a cue: The need to belong and enhanced sensitivity to social cues. Personality and Social Psychology Bulletin, v. 30, n. 9, p. 1095-1107, 2004. https://doi.org/10.1177/0146167203262085

PRINSEN, S.; EVERS, C.; DE RIDDER, D. TD. Justified indulgence: self-licensing effects on caloric consumption. Psychology \& health, v. 34, n. 1, p. 24-43, 2019. https://doi.org/10.1080/08870446.2018.1508683

RADIN, M. J. Contested commodities. Harvard University Press, 1996.

SANDHYA, A. S.; MOHAMED, H. P. Understanding the attitude of men towards fairness cream in India. Asia Pacific Business Review, v. 5, n. 2, p. 126-133, 2009. https://doi.org/10.1177/097324700900500211

SCHUTZ, W. C. The Interpersonal Underworld: By William C. Schutz. Palo Alto: Science and Behavior Books, 1966.

SEDIKIDES, C.; GREGG, A. P.; CISEK, S.; HART, C. M. The I that buys: Narcissists as consumers. Journal of Consumer Psychology, v. 17, n. 4, p. 254-257, 2007. https://doi.org/10.1016/S1057-7408(07)70035-9

SEN, A. The moral standing of the market. Social philosophy and policy, v. 2, n. 2, p. 1-19, 1985. https://doi.org/10.1017/s0265052500003186

SHUKLA, P. Impact of interpersonal influences, brand origin and brand image on luxury purchase intentions: Measuring interfunctional interactions and a cross-national comparison. Journal of world business, v. 46, n. 2, p. 242-252, 2011.

https://doi.org/10.1016/j.jwb.2010.11.002

SICILIA, M.; DELGADO-BALLESTER, E.; PALAZON, M. The need to belong and selfdisclosure in positive word-of-mouth behaviours: The moderating effect of self-brand connection. Journal of Consumer Behaviour, v. 15, n. 1, p. 60-71, 2016. https://doi.org/10.1002/cb.1533

SOUIDEN, N.; DIAGNE, M. Canadian and French men's consumption of cosmetics: a comparison of their attitudes and motivations. Journal of Consumer Marketing, v. 26, n. 2, p. 97-109, 2009. https://doi.org/10.1108/07363760910940465 
STEINER, P; TRESPEUCH M. Maîtriser les passions, construire l'intérêt. Les jeux d'argent en ligne et les organes humains à l'épreuve du marché, Revue française de sociologie, v. 54, p. 155-180, 2013. https://doi.org/ 10.3917/RFS.541.0155

STREHLAU, V. I.; CLARO, D. P; ABRAÃO NETO, S. L. A vaidade impulsiona o consumo de cosméticos e de procedimentos estéticos cirúrgicos nas mulheres? Uma investigação exploratória. Revista de Administração, v. 50, n. 1, p. 73, 2015. https://doi.org/10.5700/rausp1185

TROISI, J. D.; GABRIEL, S. Chicken Soup Really Is Good for the Soul "Comfort Food" Fulfills the Need to Belong. Psychological Science, 2011. https://doi.org/10.1177/0956797611407931

WANG, P. Z.; WALLER, D. S. Measuring consumer vanity: A cross-cultural validation. Psychology \& Marketing, v. 23, n. 8, p. 665-687, 2006. https://doi.org/10.1002/mar.20123

WATSON, J. J.; RAYNER, R. S.; LYSONSKI, S.; DURVASULA, S. Vanity and advertising: A study of the impact of appearance-related, sex, and achievement appeals. Advances in Consumer Research, v. 26, n. 1, p. 445-450, 1999

WEBER, J. M.; CAPITANT DE VILLEBONNE, J. Differences in purchase behavior between France and the USA: the cosmetic industry. Journal of Fashion Marketing and Management: An International Journal, v. 6, n. 4, p. 396-407, 2002 https://doi.org/10.1108/13612020210448673

WIGGIN, Kyra L.; REIMANN, Martin; JAIN, Shailendra P. Curiosity tempts indulgence. Journal of Consumer Research, v. 45, n. 6, p. 1194-1212, 2019. https://doi.org/10.1093/jcr/ucy055

XU, J.; SCHWARZ, N. Do we really need a reason to indulge? Journal of Marketing Research, v. 46, n. 1, 2009. https://doi.org/10.1509/jmkr.46.1.25

YE, L.; ROBERTSON, T. M. Gender Identity: Does It Matter for Consumers' Perceptions? Journal of business diversity, v. 12, n. 3, p. 81-92, 2012

Apêndice A

\begin{tabular}{|c|l|l|l|c|}
\hline \multirow{3}{*}{ Construto } & \multicolumn{1}{|c|}{ Itens da Escala } & Média & $\begin{array}{c}\text { Desvio } \\
\text { Padrão }\end{array}$ & \multirow{2}{*}{ Confiabilidade } \\
\hline \multirow{4}{*}{ Indulgência } & IND1 Eu gosto de me satisfazer. & 5,62 & 1,398 & \\
\cline { 2 - 4 } & IND2 Compro coisas para o meu prazer. & 5,14 & 1,558 & \multirow{2}{*}{0,734} \\
\cline { 2 - 4 } & IND3 Eu gosto de gastar dinheiro. & 3,68 & 1,788 & \\
\cline { 2 - 4 } & IND4 Eu compro coisas sem pensar. & 2,68 & 1,611 & \\
\cline { 2 - 4 } & IND5 Eu gosto das coisas boas da vida. & 6,05 & 1,271 & \\
\hline
\end{tabular}




\begin{tabular}{|c|c|c|c|c|}
\hline Construto & Itens da Escala & Média & $\begin{array}{l}\text { Desvio } \\
\text { Padrão }\end{array}$ & Confiabilidade \\
\hline \multirow{5}{*}{ Vaidade } & $\begin{array}{l}\text { VAI1 A maneira como eu me apresento é } \\
\text { extremamente importante para mim. }\end{array}$ & 5,44 & 1,262 & \multirow{5}{*}{0,893} \\
\hline & $\begin{array}{l}\text { VAI2 Sou muito preocupado com a minha } \\
\text { aparência. }\end{array}$ & 5,07 & 1,372 & \\
\hline & $\begin{array}{l}\text { VAI3 Sinto-me constrangido se não } \\
\text { estiver com a minha melhor aparência em } \\
\text { público. }\end{array}$ & 4,62 & 1,666 & \\
\hline & $\begin{array}{l}\text { VAI4 Vale a pena o esforço para ter um } \\
\text { melhor aspecto. }\end{array}$ & 5,14 & 1,506 & \\
\hline & $\begin{array}{l}\text { VAI5 É importante que eu apareça sempre } \\
\text { bem. }\end{array}$ & 5,24 & 1,449 & \\
\hline \multirow{8}{*}{$\begin{array}{l}\text { Suscetibilidade à } \\
\text { Influência } \\
\text { Interpessoal }\end{array}$} & $\begin{array}{l}\text { INF1 Costumo consultar outras pessoas } \\
\text { para escolher a melhor alternativa. }\end{array}$ & 4,14 & 1,648 & \multirow{8}{*}{0,885} \\
\hline & $\begin{array}{l}\text { INF2 Para ter certeza de um produto, } \\
\text { frequentemente, observo o que os outros } \\
\text { fazem. }\end{array}$ & 4,09 & 1,567 & \\
\hline & $\begin{array}{l}\text { INF3 Se eu tenho pouca experiência, eu } \\
\text { pergunto aos meus amigos. }\end{array}$ & 4,77 & 1,720 & \\
\hline & $\begin{array}{l}\text { INF4 Procuro informações junto aos } \\
\text { amigos sobre produtos antes de comprar. }\end{array}$ & 4,46 & 1,718 & \\
\hline & $\begin{array}{l}\text { INF5 Muitas vezes me identifico com } \\
\text { outras pessoas por comprar os mesmos } \\
\text { produtos. }\end{array}$ & 3,89 & 1,699 & \\
\hline & $\begin{array}{l}\text { INF6 Procuro comprar produtos que os } \\
\text { outros aprovam. }\end{array}$ & 3,89 & 1,768 & \\
\hline & $\begin{array}{l}\text { INF7 Eu gostaria de saber quais produtos } \\
\text { são bem mais aceitos pelas outras pessoas. }\end{array}$ & 3,91 & 1,799 & \\
\hline & $\begin{array}{l}\text { INF8 Sempre espero as pessoas } \\
\text { comprarem para depois eu comprar coisas } \\
\text { semelhantes. }\end{array}$ & 2,96 & 1,674 & \\
\hline \multirow{6}{*}{$\begin{array}{l}\text { Necessidade de } \\
\text { Pertencimento }\end{array}$} & $\begin{array}{l}\text { PERT1 Fico incomodado se outras } \\
\text { pessoas parecem não me aceitar. }\end{array}$ & 3,87 & 1,771 & \multirow{6}{*}{0,902} \\
\hline & $\begin{array}{l}\text { PERT2 Tento arduamente não fazer coisas } \\
\text { que farão outras pessoas evitar-me ou } \\
\text { rejeitar-me. }\end{array}$ & 3,83 & 1,837 & \\
\hline & $\begin{array}{l}\text { PERT3 Me preocupo se outras pessoas se } \\
\text { importam comigo. }\end{array}$ & 4,33 & 1,687 & \\
\hline & $\begin{array}{l}\text { PERT4 Eu preciso sentir que existem } \\
\text { pessoas com as quais posso recorrer em } \\
\text { caso de necessidade. }\end{array}$ & 4,61 & 1,680 & \\
\hline & $\begin{array}{l}\text { PERT5 Eu quero que outras pessoas me } \\
\text { aceitem. }\end{array}$ & 4,16 & 1,776 & \\
\hline & PERT6 Não gosto de ficar sozinho. & 4,19 & 1,893 & \\
\hline
\end{tabular}




\begin{tabular}{|c|c|c|c|c|}
\hline Construto & Itens da Escala & Média & $\begin{array}{l}\text { Desvio } \\
\text { Padrão }\end{array}$ & Confiabilidade \\
\hline & $\begin{array}{l}\text { PERT7 Me sinto incomodado por ficar } \\
\text { longe dos meus amigos por longos } \\
\text { períodos de tempo. }\end{array}$ & 4,43 & 1,790 & \\
\hline & $\begin{array}{l}\text { PERT8 Eu tenho uma forte "necessidade } \\
\text { de pertencer" (amigos, colegas de } \\
\text { trabalho, sociedade). }\end{array}$ & 4,20 & 1,666 & \\
\hline & $\begin{array}{l}\text { PERT9 Me incomoda muito quando eu } \\
\text { não estou incluído nos planos de outras } \\
\text { pessoas. }\end{array}$ & 3,95 & 1,674 & \\
\hline & $\begin{array}{l}\text { PERT10 Meus sentimentos são feridos } \\
\text { facilmente quando sinto que os outros não } \\
\text { me aceitam. }\end{array}$ & 3,60 & 1,835 & \\
\hline \multirow{5}{*}{$\begin{array}{l}\text { Intenção de } \\
\text { Consumo }\end{array}$} & INT1 Improvável - Provável & 4,82 & 1,696 & \multirow{5}{*}{0,960} \\
\hline & INT2 Inexistente - Existente & 4,83 & 1,730 & \\
\hline & INT3 Não Plausível - Plausível & 4,83 & 1,602 & \\
\hline & INT4 Impossível - Possível & 5,19 & 1,548 & \\
\hline & INT5 Incerta - Certa & 4,84 & 1,663 & \\
\hline
\end{tabular}

